\title{
CHAPTER 6. \\ THE SOURCES OF CODEX ZACYNTHIUS AND THEIR TREATMENT (PANAGIOTIS MANAFIS)
}

The focus of this chapter is on the identification of the sources of the scholia transmitted in the catena of Codex Zacynthius. The detailed analysis of the individual extracts and their comparison both with the direct tradition of relevant authors and with their appearance in other catena traditions yields interesting results with regard to their source and textual transmission. The examination of differences, omissions and additions enables us to develop an understanding of how the sources have been employed and adjusted by the compilers of catenae as well as to gain some insight into their subsequent history. Copying practice in Codex Zacynthius is also considered.

\section{The Collection of Exegetical Passages}

Catenae are chains of extracted exegetical comments on the books of the Bible. ${ }^{1}$ In the past, scholarship has disputed the originality of texts consisting of selections, deeming the cut-and-paste technique employed in these works to be a sign of intellectual decline. ${ }^{2}$ Collections of extracted exegetical passages were only studied as sources for the patristic authorities that they preserved. More recently, however, there has been a shift towards considering such compilations as texts in their own right, seeking their originality in the new combination of extracts into a fresh work. ${ }^{3}$ Indeed, scholarship of the last decade has begun to view collections of excerpts as a particular way of ordering, organising and disseminating knowledge in Byzantium. Odorico has described Byzantine society as 'a

\footnotetext{
${ }^{1}$ On catenae manuscripts see Robert Devreese, 'Chaînes exégétiques grecques,' in Dictionnaire de la Bible: Supplément, ed. A. Pirot (Paris: Letouzey et Ané, 1928) cols. 1084-1233; Nigel G. Wilson, 'A Chapter in the History of Scholia,' Classical Quarterly 17.2 (1967): 244-56; Gilles Dorival, Les chaînes exégétiques grecques sur les Psaumes: contribution à l'étude d'une forme littéraire. 4 vols. (Leuven: Peeters, 1986-95); Jean-Marie Auwers, ed., Procopii Gazaei Epitome in Canticum Canticorum. CCSG 67 (Turnhout: Brepols, 2011); H.A.G. Houghton and D.C. Parker, 'An Introduction to Greek New Testament Commentaries with a Preliminary Checklist of New Testament Catena Manuscripts,' in Commentaries, Catenae and Biblical Tradition (ed. H.A.G. Houghton. T\&S 3.13. Piscataway NJ: Gorgias, 2016), 1-35.

${ }^{2}$ S. Dusil, G. Swedler, R. Schwitter, ed., Exzerpieren-Kompilieren-Tradieren. Transformationen des Wissens zwischen Spätantike und Frühmittelalter (Berlin: De Gruyter, 2017).

${ }^{3}$ See the special issue of Byzantinoslavica 75 (2017) edited by Paolo Odorico; also, P. Manafis, (Re)writing History in Byzantium: A Critical Study of Collections of Historical Excerpts (Abingdon \& New York: Routledge, 2020).
} 
culture of sylloge, ${ }^{4}$ and scholars have begun to consider sylloges of excerpts in their individuality and within the particular context they appeared. Such an approach has been promoted by the recent turn to study manuscripts in their own right, rather than as mere sources for the ancient texts they preserve. ${ }^{5}$ Collections of patristic citations, however, have long attracted particular scholarly attention. On one hand, citations from authoritative sources undoubtedly enhanced the validity of arguments in religious rivalries and dogmatical disputes. ${ }^{6}$ On the other hand, such collections of extracts offered a unified and cogent vision of the present on the basis of extant pieces of representations of the past. Yet textual interventions in the original were involved in the creation of a work in a new format which provided a compilation of exegetical comments. ${ }^{7}$ Besides, certain chains of exegetical extracts became fixed texts and continued to be copied as independent works throughout the Byzantine millennium and beyond. Considering catenae as autonomous pieces of literature, therefore, Codex Zacynthius is of great value in reconstructing the oldest recoverable text of patristic extracts transmitted in the tradition of catenae on Luke. ${ }^{8}$ In other words, catenae manuscripts can be helpful in retrieving original commentaries on the Bible but they should be studied with extreme caution, for a catena was intended to create a new commentary on the basis of various extracts rather than to preserve an existing commentary.

\section{THE SOURCES}

While the previous chapter considered the way in which the scholia are presented in Codex Zacynthius, the examination of their text in the light of the writings which have been preserved from antiquity enables us to consider their sources in greater detail. As a result of the work of identification undertaken by the Codex Zacynthius Project (presented in the List of Catena Contents on pp. 73-95). Table 6.1 summarises the contents of the catena based on the textual analysis of each extract. Because there are a few occasions when what is presented as a single scholium in the manuscript actually consists of a combination of multiple sources, there are more items listed here than in Table 5.2; scholia where the attribution is doubtful have provisionally been assigned to the author.

\footnotetext{
${ }^{4}$ Paolo Odorico, 'La cultura della $\Sigma u \lambda \lambda o \gamma \eta$ ' 1) Il cosiddetto enciclopedismo bizantino. 2) Le tavole del sapere di Giovanni Damasceno,' Byzantinische Zeitschrift 83.1 (1990): 1-21.

${ }^{5}$ Filippo Ronconi, I manoscritti greci miscellanei. Ricerche su esemplari dei secoli IX-XII. (Spoleto: CISAM, 2007); Eva Nyström, Containing Multitudes: Codex Upsaliensis Graecus 8 in Perspective. Studia Byzantina Upsaliensia 11 (Uppsala: Uppsala Universitet, 2009); Alessandro Bausi, ed., Comparative Oriental Manuscript Studies: An Introduction (Hamburg: COMSt, 2015).

${ }^{6}$ On this see Thomas Graumann, Die Kirche der Väter. Vätertheologie und Väterbeweis in den Kirchen des Ostens bis zum Konzil von Ephesus (431). Beiträge zur Historischen Theologie 118 (Tübingen: Mohr Siebeck: 2002).

${ }^{7}$ See the examples presented below.

${ }^{8}$ This observation is also made by Reuss, who describes Codex Zacynthius as 'die wohl älteste Lukas-Katene' (Joseph Reuss, Lukas-Kommentare aus der griechischen Kirche. TU 130 [Berlin: Akademie, 1984], xv).
} 


\begin{tabular}{|l|c|c|c|c|}
\hline Author & $\begin{array}{c}\text { Total } \\
\text { extracts }\end{array}$ & $\begin{array}{c}\text { Direct } \\
\text { tradition }\end{array}$ & $\begin{array}{c}\text { Other } \\
\text { catenae }\end{array}$ & $\begin{array}{c}\text { Unpub- } \\
\text { lished }\end{array}$ \\
\hline Cyril of Alexandria & 151 & 1 & 150 & 0 \\
\hline Origen & 67 & 29 & 38 & 0 \\
\hline Titus of Bostra & 48 & 0 & 47 & 1 \\
\hline Severus of Antioch & 38 & 0 & 33 & 5 \\
\hline Victor the Presbyter & 7 & 0 & 4 & 3 \\
\hline John Chrysostom & 5 & 5 & 0 & 0 \\
\hline Isidore of Pelusium & 4 & 4 & 0 & 0 \\
\hline Eusebius of Caesarea & 4 & 0 & 4 & 0 \\
\hline Basil of Caesarea & 4 & 4 & 0 & 0 \\
\hline Apollinarius & 1 & 0 & 1 & 0 \\
\hline Unidentified & 14 & 0 & 9 & 12 \\
\hline Total & 343 & $43(12.5 \%)$ & $286(83.4 \%)$ & $14(4.1 \%)$ \\
\hline
\end{tabular}

Table 6.1: Identification of scholia sources.

The first observation to be drawn from this overview is that the examination of the text results in the attribution of the extracts to the same ten writers as are named in the titles of the extracts. While there are twelve titles in the manuscript which appear to be inaccurate, no additional authors have been identified. ${ }^{9}$ This indicates a relatively fixed corpus of writings from which the scholia in this catena were drawn, in contrast to the appearance of other sources such as Athanasius of Alexandria, Gregory of Nazianzus, and Gregory of Nyssa in other catenae. ${ }^{10}$ What is more, the fact that the vast majority of attributions in Codex Zacynthius appear to be correct suggests that this manuscript is a faithful witness to the catena tradition it transmits, as might also be surmised from its early date. The information about the tradition of the scholia serves to demonstrate the importance of the catena tradition in preserving writings which have otherwise been lost: only $12.5 \%$ of the scholia in Codex Zacynthius are known today through the direct tradition of an author's work, although over $83 \%$ are present in other editions of catenae. At the same time, this reliance on catenae alone means that some of the identifications should be treated with caution. Fortunately, in the case of Cyril of Alexandria, the preservation of extensive portions of his Homilies on Luke in a literal Syriac translation provides confirmation for the attribution of the majority of the extracts in this catena as well as shedding light on the compiler's patterns of excerpting.

\footnotetext{
${ }^{9}$ The inaccurate titles are for scholia 040-1, 041-1, 042-1, 061-2, 186-1, 186-2. 188-2, 271-1, 276-1, 277-1, 301-1, 306-2. These are discussed further below.

${ }^{10}$ These authors feature heavily in type C130 of the Catenae on Luke; Reuss, Lukas-Kommentare, xi; see also pages $140-2$ below.
} 
In the following part of this chapter, the sources for the scholia are considered in roughly chronological order. The 'unattributed collection' (' $\xi \dot{\xi} \nu \varepsilon \pi \tau \gamma \rho \dot{\alpha} \varphi \circ v)$ is taken first, on the assumption that it precedes the rest of the compilation of Codex Zacynthius. This is followed by Origen, Eusebius and Basil of Caesarea, Apollinarius of Laodicea, John Chrysostom, Isidore of Pelusium, Titus of Bostra, Cyril of Alexandria, Victor the Presbyter, and Severus of Antioch. References to other catenae on Luke use the designations in the Clavis Patrum Graecorum (C130-C139) or the individual manuscript shelfmark. ${ }^{11}$

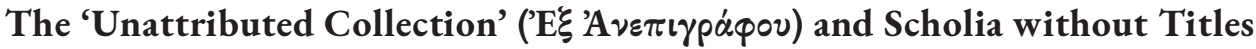

Thirty-two scholia in Codex Zacynthius were copied with the heading $\dot{\xi} \xi \dot{\alpha} \nu \varepsilon \pi \imath \gamma \rho \dot{\alpha} \varphi o v$, with a further ten attributed by implication to this source. It is probable that these comments come from a collection in which extracts were not attributed to any patristic authority, given that they derive from a variety of authors and yet are all identified in this similar way. A considerable number of them can be securely identified, although nine remain unidentified. ${ }^{12}$ Fourteen come from Cyril of Alexandria, twelve from Origen, four from Titus of Bostra, and one is attributed to Eusebius in other catenae (023-1). Two of them correspond to extracts from Severus of Antioch in Mai's collection (043-1, 072-1). ${ }^{13}$ Ten extracts in Codex Zacynthius have been transmitted without any source identification in the heading. ${ }^{14}$ In many cases this is likely to be through scribal oversight, although it is striking that five of the first six scholia have no formal identification. Four of the scholia are described as 'other'. The adverb $\alpha \lambda \lambda \omega \varsigma$ is used for two extracts from Origen's Commentary on John, which follow another excerpt from this work (001-3 and 001-4). The two scholia designated as $22 \lambda$ os cannot be identified (199-2, 200-1), but they do not appear to derive from the same source as the preceding comment. It is interesting that they occur so close to each other and that, unlike the other scholia, the title is in the nominative rather than the genitive. Nevertheless, as 200-1 is the only comment on this numbered catena section, it is clearly part of the original compilation. Twenty further passages lack any source identification due to the fact that the initial portion of the scholium is missing. In keeping with the general pattern of this compilation, eleven of these may securely be assigned to Cyril's commentary on Luke while three are by Origen, three from Severus and one each from Victor and Titus. The sole remaining one also appears in the catena printed by Cramer (326-1).

\footnotetext{
${ }^{11}$ On these catena types see further Chapter 8 below. The use of C137.7 to designate the catena in Paris, BnF, Suppl. grec 612, and C139.1 for the catena of four manuscripts (some of which were previously listed under C137 without a catena type) are innovations of the CATENA project in conjunction with the Clavis Clavium database.

${ }^{12}$ Scholia 008-1, 009-1, 011-1, 014-1, 061-1, 185-1, 187-1, 188-1, 241-1.

${ }^{13}$ Scholium 072-1 is attributed to Peter of Laodicea by C.F.G. Heinrici, Beiträge zur Geschichte und Erklärung des Neuen Testamentes. III.2 Aus der Hinterlassenschaft des Petrus von Laodicea (Leipzig: Dürr, 1905), 114, but this is based on a very late manuscript and the Severan identification takes precedence.

${ }^{14}$ Scholia 001-2, 002-1, 003-1, 032-3, 041-2, 129-1, 138-1, 198-1, 235-2, 311-3.
} 


\section{Origen}

Thirty-four passages in Codex Zacynthius are presented under the name of Origen (c.185c.253). This is frequently given in abbreviation, as $\dot{\omega} \rho(1 \gamma \dot{\varepsilon} v 0 u \varsigma)$. A further thirty-three may be assigned to Origen, either because of their attribution in other catenae or in the direct tradition of his works. Origen wrote exegetical comments on most of the books of the New Testament. His Homilies on Luke survive in Greek fragments and in a Latin translation by Jerome, which are followed in Rauer's edition by a lengthy appendix of scholia on Luke attributed to Origen. ${ }^{15}$ Twenty-six of the extracts in Codex Zacynthius can be securely identified as originating from Origen's Homilies on Luke, while many of the others appear among Rauer's fragments. ${ }^{16}$ As noted above, there are three extracts from his Commentary on John at the opening of the Gospel, defining the word $\varepsilon \dot{v} \alpha \gamma \gamma \dot{\varepsilon} \lambda ı$, two of which have the title $\alpha \lambda \lambda \omega$. $^{17}$ In the first of these, extract 001-2, Codex Zacynthius (C137.3) and the catena on Luke known as C131 share two readings against the direct tradition of Origen, as indicated by the underlined text in Table 6.2. ${ }^{18}$ In Codex Zacynthius, the original text was supplemented with an introduction apparently from the compiler himself (in bold in Table 6.2). The possibility that Origen's text was reworked by the compiler of Codex Zacynthius and then made its way into the broader Lukan catena tradition cannot be excluded, although the absence of the introductory phrase elsewhere suggests rather that both Codex Zacynthius and C131 were drawing on a shared source.

\begin{tabular}{|c|c|c|}
\hline C137.3 & $\mathrm{C} 131^{19}$ & Origen \\
\hline 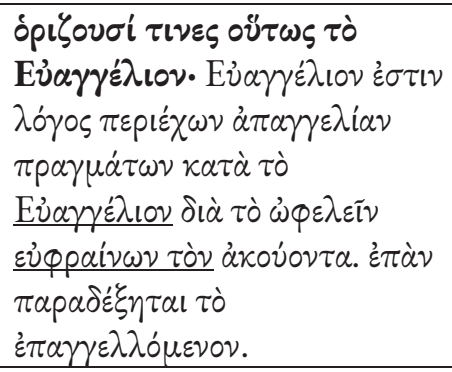 & 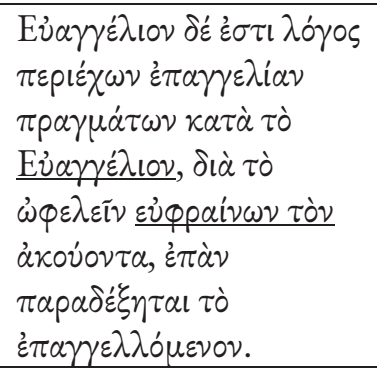 & 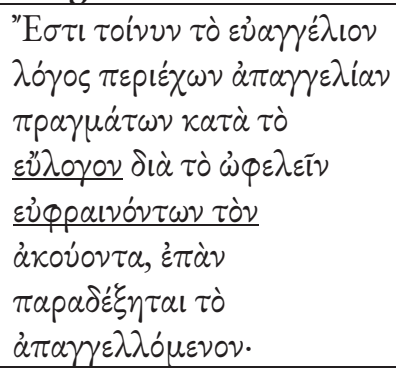 \\
\hline
\end{tabular}

Table 6.2: The text of scholium 001-2.

${ }^{15}$ See Max Rauer, Origenes: Werke IX. Die Homilien zu Lukas. Second edn. GCS 49 (Berlin: Hinrichs, 1959); this is the basis for Joseph T. Lienhard, trans., Origen: Homilies on Luke, Fragments on Luke (Fathers of the Church 94. Washington DC: Catholic University of America, 1996). See also H. Crouzel, F. Fournier and P. Périchon, Origène. Homélies sur saint Luc. SC 87 (Paris: Cerf, 1962).

${ }^{16}$ 006-1, 014-1, 024-1, 025-1, 027-1, 032-1, 041-1, 041-2, 042-1, 046-2, 047-1, 062-1, 063-1, 064-1, 074-1, 078-1, 104-1, 106-1, 106-3, 111-1, 115-1, 116-1, 117-1, 128-1, 297-1, 302-2.

${ }^{17}$ 001-2, 001-3 and 001-4; cf. Cécile Blanc, Origène. Commentaire sur saint Jean, I. SC 120 (Paris: Cerf, 1966), 1.5.7.1-6, and 1.5.27.8-10.

${ }^{18}$ On C131, see pages 147-53 below; in fact, it attributes this scholium to John Chrysostom, as noted on page 105 .

${ }^{19}$ The sources for C131 here are Paris, BnF, Coislin grec 23 (fol. 149r); Coislin grec 195 (fol. 241r). 
Twelve of the passages indicated as $\dot{\xi} \xi \dot{\alpha} v \varepsilon \pi \imath \gamma \rho \dot{\alpha} \varphi \circ v$ can be securely identified as Origen. ${ }^{20} \mathrm{~A}$ short passage copied in the right margin of folio $8 \mathrm{v}$ is a reworked version of a

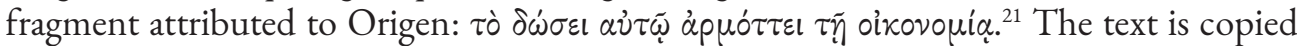
next to a scholium on Luke 1:32 attributed to Severus of Antioch (032-2). The nature of this extra comment, apparently copied by the first hand, is uncertain, but it occurs as an independent extract in C131. We may note that this scholium is not found in the single witness to C137.7, a catena which appears to be a descendant of the type found in Codex Zacynthius (Paris, BnF, suppl. gr. 612, discussed in Chapter 8). All that can be said is that it is a comment on Luke that circulated in the catena tradition. It might have been copied as an additional comment on Luke 1:32 or as an addition to the quotation from Severus in the catena text.

Scholium 046-1 transmits a comment on Luke 1:43 under the heading $\dot{\xi} \xi$

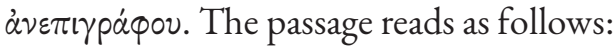

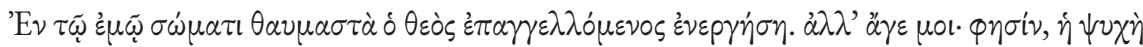

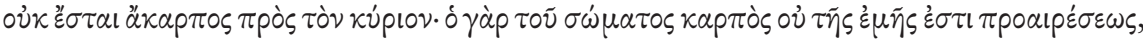

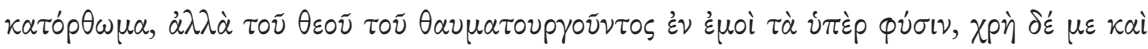

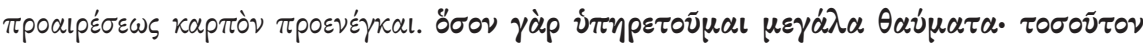

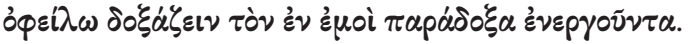

The first part of this scholium (identified as 046-1a) comes from Origen's Homilies on Luke. .2 $^{22}$ The additional text, marked in bold and indicated as $046-1 \mathrm{~b}$ in our transcription, can be found in two sources: 1) at the end of a scholium on Luke 1:46 labelled as $\dot{\varepsilon} \xi$

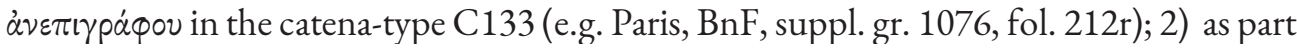
of an anonymous comment on Luke 1:43 in the catena-type C131 (e.g. Paris, BnF, Coislin grec 23, fol. 151r and Coislin grec 195, fol. 245r).

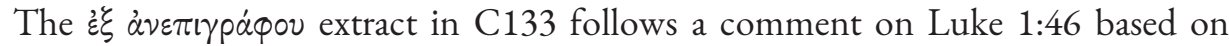
Origen, but the text of the Origen scholium in Codex Zacynthius is not included. The text of this unpublished excerpt from the unattributed collection is as follows:

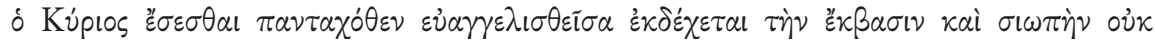

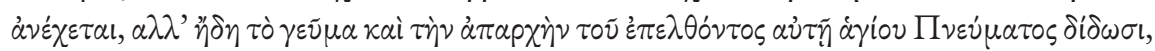

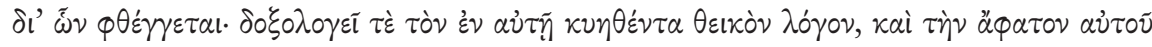

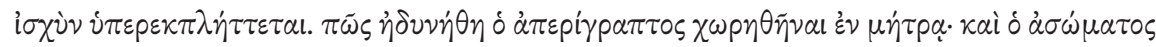

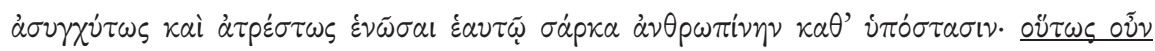

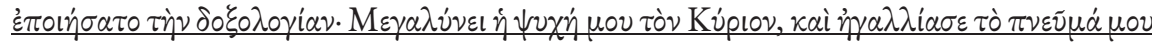

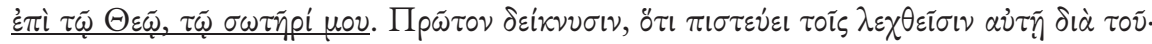

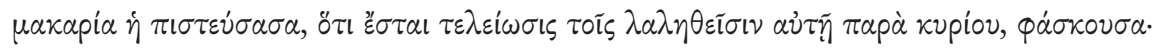

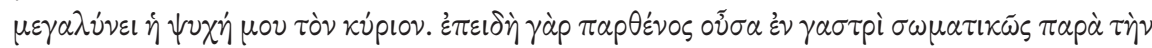

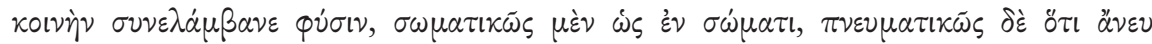

\footnotetext{
${ }^{20}$ 005-1, 014-1, 044-1, 045-1, 046-1ab, 047-1, 048-1, 049-1, 050-1, 063-1, 064-1, 073-1, 244-1.

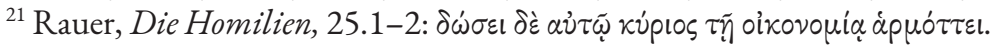

${ }^{22}$ Rauer, Die Homilien, 38a, 38b.
} 


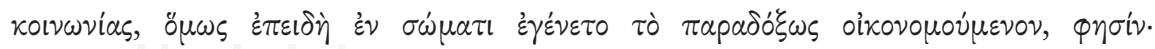

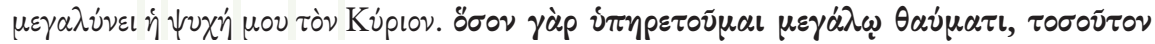

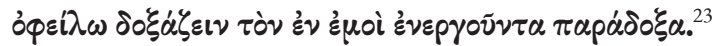

This scholium is a compilation. It has not been possible to assign the initial portion ( $\delta$ Kúpı

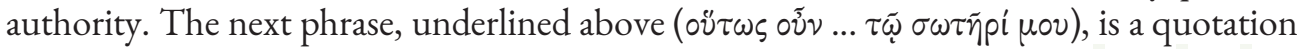

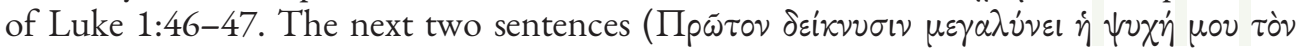
Kúpıv) are from Origen's Homilies, followed by a slightly different version of the extra line in Codex Zacynthius. ${ }^{24}$ The comment in C131 reads:

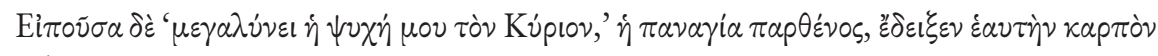

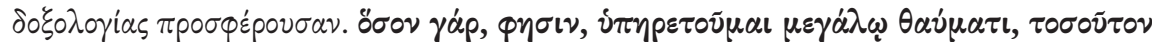

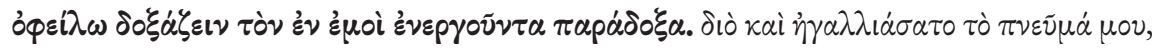

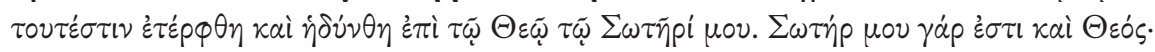

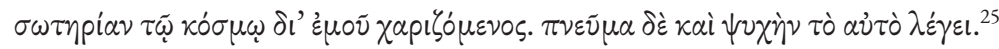

This too is a composite text, which appears to come from the same source as the $\dot{\varepsilon} \xi$

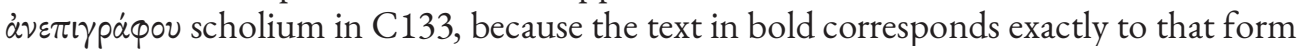
rather than the version in extract 046-1b. It thus seems that the compiler of the catena in

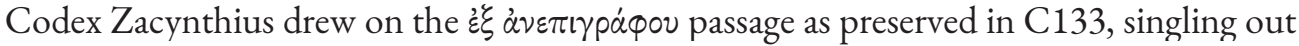
the short final section and adding this to a different $\dot{\varepsilon}^{\xi} \dot{\alpha} \dot{\alpha} \varepsilon \pi \iota \gamma \rho \alpha \dot{\varphi} \varphi \nu$ extract, thus creating a new comment on Luke 1:46. C137.7 does not contain scholium o46-1.

A compiler has also intervened in scholium 044-1, another $\dot{\xi} \xi \dot{\alpha} \nu \varepsilon \pi \iota \gamma \rho \dot{\alpha} \varphi \circ v$ text which derives from Origen. This extract is made up of the following passages: a) Rauer's fragment 32b, copied verbatim; b) Rauer's fragment 33b, abbreviated; c) Rauer's fragment 32a, copied verbatim; d) a citation of Luke 1:42; and e) Rauer's fragment 33a, slightly altered

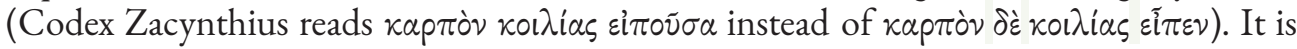
impossible to say whether this redactional activity is that of the compiler of Codex Zacynthius or the $\dot{\xi} \xi \dot{\alpha} \nu \varepsilon \pi \imath \gamma \rho \dot{\alpha} \varphi \circ$ collection. Similarly, what is presented as a single scholium for catena section 297 combines two different texts from Origen: a portion from Homily 34 on Luke into which Rauer's fragment 166 has been inserted.

In the catena classified as C131, a paraphrased text clearly related to scholium 050-1 appears as the second part of a longer comment on Luke 1:49 by Origen. ${ }^{26}$ The extract in Codex Zacynthius amplifies the comment by repeating the biblical quotation: ह่ $\pi \circ$ in $\sigma \dot{\varepsilon} \nu$

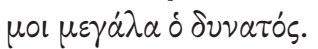

In later scholia, the attribution to Origen is indicated by an $\omega p$ monogram rather than the full name (e.g. scholia 295-2, 297-1, 302-2, 307-1). Scholium 311-3 on folio LXXXVIIv lacks any source indication: the initial paragraphos and enlarged capital appear to have

\footnotetext{
${ }^{23}$ This is transcribed from Paris, BnF, suppl. gr. 1076, fol. 212r.

${ }^{24}$ Rauer, Die Homilien, 37.

${ }^{25}$ C131 (Paris, BnF, Coislin grec 23, fol. 245r; Coislin grec 195, fol. 151r).

${ }^{26}$ John Anthony Cramer, Catenarum Graecorum Patrum in Novum Testamentum. Tomus II in Evangelia S. Lucae et S. Joannis (Oxford: OUP, 1844) 14.33-15.4.
} 
been put two sentences too early, as these are a continuation of the previous scholium

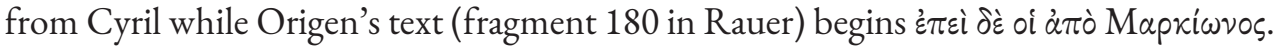

\section{Eusebius and Basil}

Four scholia in Codex Zacynthius (033-2, 038-1, 039-1, 042-1) are attributed to Eusebius of Caesarea (c.263-339/40) and three extracts (086-1, 087-1, 088-1) bear the name of Basil of Caesarea (329/30-379). It is striking that these appear as two relatively self-contained groups, suggesting that each derives from a work which commented on a single passage. In the case of Basil, this is definitely the case: all three come from his Letter 260, addressed to Optimus the Bishop of Antioch. ${ }^{27}$ The exact source for the comments from Eusebius is less clear: a series of fragments on Luke ascribed to him is published in PG 28 (col. 529605), which includes scholia 033-1, 038-1 and 039-1. Scholium 023-1, which has the title $\dot{\xi} \xi \dot{\alpha} \nu \varepsilon \pi \imath \gamma \rho \alpha \dot{\varphi} \circ 0$, is also found in this series and may accordingly be identified as Eusebius. The attribution of 042-1 to Eusebius is, however, false: this derives from a homily on Luke by Origen. ${ }^{28}$ Scholium 306-2, which has the heading $x \alpha i ̀$ $\pi \dot{\lambda} \iota \nu$ and follows an extract from Titus of Bostra, is from Basil's ascetic sermon on prayer. ${ }^{29}$

\section{Apollinarius}

A single extract in the catena of Codex Zacynthius, namely 221-3, is attributed to Apollinarius of Laodicea (c.315-c.392). Apollinarius wrote commentaries on several books of the Old and New Testament, which survive in fragments through catena manuscripts. Reuss includes twenty excerpts from Apollinarius from catenae on Luke, nineteen of which are encountered in the manuscript Vatican, BAV, Vat. gr. 1611, i.e. the catena by Nicetas of Heraclea (C135). ${ }^{30}$ It is noteworthy that 221-3, a short extract from the middle of Reuss's fragment 1 , is not contained in the catena of Nicetas. As Reuss has shown that at least thirteen of these twenty excerpts can be ascribed to Apollinarius' commentary on the Gospel according to Matthew, it is quite likely that the rest of the surviving fragments by Apollinarius which are preserved in catenae manuscripts on Luke also come from this work. ${ }^{31}$ This is certainly the case for $221-3$, because it is also transmitted in catenae manuscripts of the Gospel according to Matthew as a scholium on

\footnotetext{
${ }^{27}$ Basil, Letters, Volume IV: Letters 249-368. On Greek Literature. Translated by Roy J. Deferrari and M.R.P. McGuire. Loeb Classical Library 270 (Cambridge MA: Heinemann, 1934).

${ }^{28}$ Rauer, Die Homilien, 7.41.16-42.7.

${ }^{29}$ PG 31, 1328.

${ }^{30}$ Reuss, Lukas-Kommentare, 3-10; Joseph Sickenberger, Die Lukaskatene des Niketas von

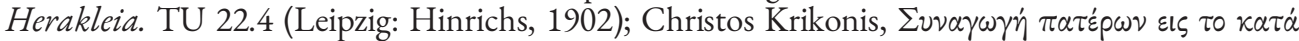

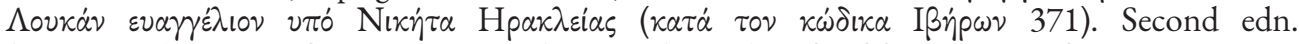
(Thessaloniki: Centre for Byzantine Studies, 1976), 47 identifies fifteen extracts from Apollinarius in Iviron 371.

${ }^{31}$ Reuss, Lukas-Kommentare, xxi. See also the critical apparatus accompanying the passages from Apollinarius in that volume.
} 
Matthew 5:15.32 There are two minor differences between the text of the Matthaean

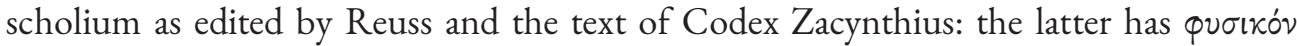

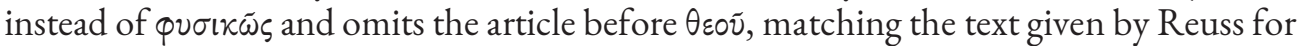
the Lukan version of this scholium. ${ }^{33}$

The extract which precedes 221-3 is from Origen. In the catena type C132, Origen's comment on Luke 8:16 and Apollinarius' comment on Matthew 5:15 are joined together as a single passage without any indication of the author, thereby obscuring their separate sources. $^{34}$ In contrast, 221-3 appears in the catena C134 as part of a longer scholium attributed to Apollinarius. ${ }^{35}$ This must therefore have been taken from a different source to that of the catena of Codex Zacynthius.

\section{John Chrysostom}

Five scholia in Codex Zacynthius are attributed to John Chrysostom (c.347-407). There is a slight variation in Chrysostom's titles: he is referred to as bishop ( $\dot{\varepsilon} \pi\llcorner\sigma \kappa o ́ \pi \circ v)$ in 001-1,

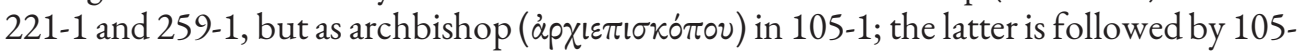

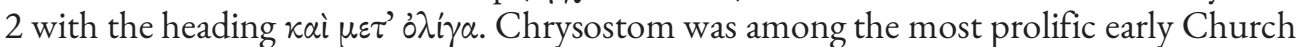
Fathers. His expositions of the books of the Bible have been transmitted in the form of homilies through a very rich manuscript tradition, and were heavily extracted in collections of exegetical passages. Given that Chrysostom is the most frequently quoted author by far in the catena on Luke by Nicetas of Heraclea (C135), the small number of comments in Codex Zacynthius is striking. ${ }^{36} \mathrm{It}$ is also notable that all five excerpts come from John Chrysostom's Homilies on Matthew rather than his exposition of Luke. ${ }^{37}$

No additional scholia have been identified as from Chrysostom, although it may be noted that extract OoI-2, which has no title, is ascribed to John Chrysostom in the manuscripts of the catena Ci3I. ${ }^{38}$ In that catena, this extract is joined to the previous scholium which is universally assigned to John Chrysostom (ooI-I in Codex Zacynthius). Nevertheless, as discussed above, this brief sentence is taken from Origen's commentary

\footnotetext{
${ }^{32}$ See Joseph Reuss, Matthäus-Kommentare aus der griechischen Kirche. TU 61 (Berlin: Akademie, 1957), 5. As noted below, the extracts transmitted under the name of John Chrysostom in Codex Zacynthius also appear to have been taken from his Homilies on Matthew.

${ }^{33}$ The text of Codex Zacynthius is identical to this scholium in Paris, BnF, suppl. gr. 612, fol. 226r.

${ }^{34}$ E.g. Vienna, ÖNB, Theol. gr. 117, fol. 146v (saec. x); Vatican, BAV, Vat. gr. 358, fol. 206 (saec. xi) and Vat. gr. 758, fol. 31r (saec. xii); Paris, BAV, Coisl. gr. 20, fol. 269 (saec. x). On the catena type C132, see further Chapter 8.

${ }^{35}$ This is the whole of Reuss's fragment 1 on Luke. The two manuscripts of C134 are Vatican, BAV, Pal. gr. 20, fol. 79 (saec. xiv) and Vat. gr. 1933, pp. 199-200 (saec. xvii).

${ }^{36}$ See page 124 below.

${ }^{37} P G$ 57: 16.19-23; $P G$ 57: 187.44-54; $P G$ 57: 232.32-37; $P G$ 58:549.55-550.15; $P G$ 57: 188.410.

${ }^{38}$ E.g. Paris, BnF, Coislin grec 23, fol. 149r; Coislin grec 195, fol. 241r; see page 101 above.
} 
on the Gospel according to John and the variations between the text in both catenae and the direct tradition of Origen suggest that it was taken from a common secondary source.

The portion of Chrysostom's Homily I (De cruce et latrone) quoted by Severus of Antioch in his Letter to Caesaria the Noblewoman (scholium 082-I) is worthy of mention. Its text is almost identical to that of Montfaucon's edition, the variants being $\sigma \varphi \alpha \dot{\zeta} \varepsilon \tau \alpha l$ for $\sigma \varphi \dot{\alpha} \tau \tau \varepsilon \tau \alpha$ l and $\kappa \alpha \theta \dot{\alpha} p \eta$ for $\dot{k} \kappa \alpha \theta \dot{\alpha} p \eta$. This quotation is marked with the same diplai as biblical references: the only other instance of this for a patristic text is the quotation of Cyril of Alexandria in the catena preface.

\section{Isidore of Pelusium}

Four extracts in Codex Zacynthius are attributed to Isidore of Pelusium (360-449/50?). Isidore's biblical commentaries took the form of letters, of which a corpus of no fewer than 2,012 survive. ${ }^{39}$ Three of the scholia specify the number of the letter from which they are taken: Epistle 363 in 045-3; Epistle 48 in 075-3 and Epistle 1759 in 298-2. Scholium 024-3 simply gives the author as 'Isidore the presbyter of Pelusium', and comes from an Epistle on Divine Interpretation. All four scholia are also included in the catena of Nicetas (C135). The final scholium, 298-2, is worthy of further attention. Isidore's text is abridged in C135 and paraphrased in C131, but C137.3 and C137.7 are identical and correspond very closely to the direct tradition of Isidore as shown in Table 6.3. This also illustrates how the passage in C131 derives from a different exegetical tradition. ${ }^{40}$

\begin{tabular}{|c|c|c|c|}
\hline Isidore, Epistle 1759 & $\begin{array}{l}\text { C137.3, C137.7 } \\
\text { (Cod. Zacynthius) }\end{array}$ & $\begin{array}{l}\text { C135 } \\
\text { (Iviron 371) }\end{array}$ & $\begin{array}{l}\text { C131 (Cramer, } \\
2.87 .32-88.10)\end{array}$ \\
\hline 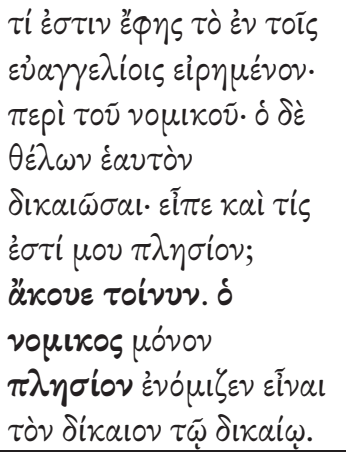 & 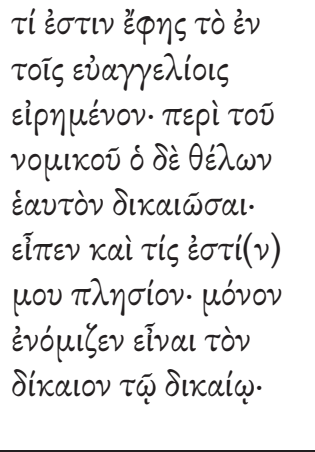 & 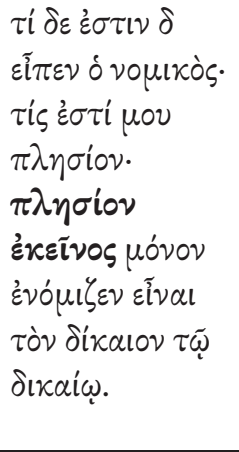 & 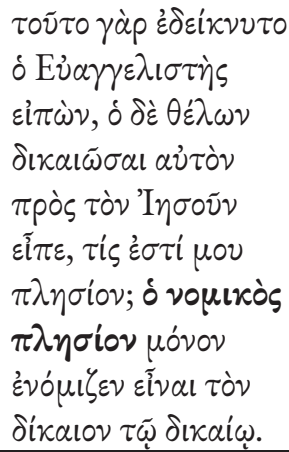 \\
\hline
\end{tabular}

Table 6.3: Scholium 298-2 (Isidore, Epistle 1759).

\footnotetext{
${ }^{39}$ The entire corpus epistularum is published in PG 78, 177-1048. See further P. Évieux, Isidore de Péluse. Lettres, I: Lettres 1214-1413. SC 422 (Paris: Cerf, 1997); P. Évieux, Isidore de Péluse, Lettres, II, Lettres 1414-1700. SC 454 (Paris: Cerf, 2000); P. Évieux and N. Vinel, Isidore de Péluse III, Lettres 1701-2000. SC 586 (Paris: Cerf, 2017). On the manuscript transmission of Isidore's letters see also Madalina Toca, 'The Greek Manuscript Reception of Isidore of Pelusium's Epistolary Corpus,' Biblische Notizen 175 (2017): 133-43.

${ }^{40}$ On the relationship between C131 and the catena of Codex Zacynthius, see further pages 14753 below.
} 


\section{Titus of Bostra}

Forty-nine extracts in Codex Zacynthius are attributed to Titus of Bostra. In the latter part of the fourth century he composed a commentary on the Gospel of Luke which is now only preserved in fragments in catenae. ${ }^{41}$ Textual analysis reduces the number of genuine scholia from Titus to forty-eight: on six occasions Titus is incorrectly identified in Codex Zacynthius as the source of an extract from the commentary by Cyril of Alexandria (1861 [and by implication 186-2], 188-2, 271-1, 276-1 and 277-1), although he is the author of

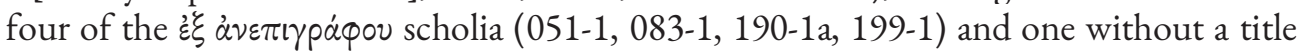
(261-1). As noted in Table 6.1, all of the extracts from Titus are transmitted in other catenae except one. This is scholium 184-1, a single sentence at the top of folio XLIv commenting on Luke 6:46:

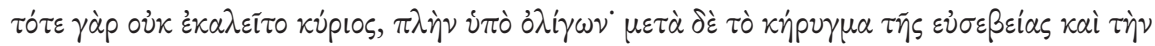

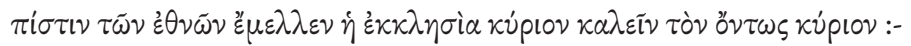

It has not been possible to identify this text and it could be an otherwise unattested extract from Titus: Sickenberger's collection has no comment from Titus between Luke 6:44 and $7: 1 .^{42}$ At the same time, Reuss includes it in the third series of his scholia from Cyril of Alexandria because of its appearance in a single manuscript of the catena C133. ${ }^{43}$ Sickenberger's ascription to Titus of the comments on Luke 7:1 (186-1 and 186-2) and Luke 10:2(277-1) is now rendered doubtful by the exact match of these extracts with the Syriac version of Cyril's Commentary on Luke: only if Cyril were making an unacknowledged verbatim citation of Titus could this be upheld (see also the analysis of scholium 188-2 in the next section, on Cyril of Alexandria). Sickenberger notes, however, that scholium 276-1 on Luke 10:1 is from Cyril even though it is also identified as Titus in C131 (and appears without any attribution in C135). ${ }^{44}$

Given the importance of his commentary, it is striking that the first comment from Titus does not occur until Luke 1:50 (051-1), which is not expressly attributed to him but is instead marked as $\dot{\xi}^{\xi} \dot{\alpha} \nu \varepsilon \pi \imath \gamma \rho \alpha \dot{\varphi}$ ov. The next extract of his is scholium 074-2 on Luke 2:1.

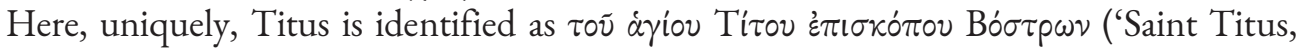
Bishop of Bostra') and one might speculate that there is a connection between this full introduction and the fact that this is the first scholium attributed to Titus. In the latter part of Codex Zacynthius, the scholia from Titus become more frequent: between fol. XL and LXXXVIII Titus represents just under one in four of the total scholia, being the source of thirty-seven extracts. One textual variant may be noted: in scholium 225-1, Codex

${ }^{41}$ Many are collected in Joseph Sickenberger, Titus von Bostra. Studien zu dessen Lukashomilien. TU 21.1 (Leipzig: Hinrichs, 1901) 140-245. Manuscripts of the earliest catena on Luke (C130) often attribute it to Titus, although it is a sixth-century creation which draws heavily on Titus's commentary as well as Cyril, John Chrysostom and Origen: see Chapter 8.

${ }^{42} \mathrm{It}$ is also found in Paris, BnF, suppl. gr. 612, fol. 177v.

${ }^{43}$ Reuss, Lukas-Kommentare, 285 (frag. 44): Paris, BnF, suppl. gr. 1076, fol. 242r.

${ }^{44}$ Sickenberger, Titus von Bostra, 186-7; for C131 see Paris, BnF, Coislin gr. 23, fol. 173v; Coisl. gr. 195, fol. 285r, while for C135 see Iviron 371, fol. 368v; Paris, BnF Coisl. gr. 201, fol. 266; Paris, BnF, gr. 208, fol. 319r. This extract is fr. 100 in Reuss, Lukas-Kommentare, 106. 
Zacynthius reads $\sigma \nu \gamma \gamma \varepsilon \nu \tilde{\omega} \nu$ whereas the reading $\varepsilon \dot{\nu} \gamma \varepsilon \nu \tilde{\omega} \nu$ occurs in the same extract preserved in manuscripts bearing the catena classified as C131.

\section{Cyril of Alexandria}

A total of one hundred and nine comments in Codex Zacynthius are assigned by name to Cyril of Alexandria (c.375-444). All of these appear to be correctly assigned, and Cyril is also the source for fourteen of the scholia marked as $\dot{\xi} \xi \alpha \nu \varepsilon \pi \imath \gamma \rho \alpha \dot{\varphi} \varphi v$ and twenty-eight extracts whose title is missing, resulting in a total of one hundred and fifty-one extracts. This makes him the most frequently quoted author in the catena (not to forget the quotation from this Letter to Eulogius in the preface). ${ }^{45}$ Almost all of the scholia appear to be from Cyril's Commentary on Luke or other fragments related to this gospel. The one definite exception is extract 087-2, which is explicitly identified as coming from his

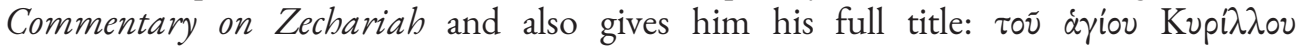

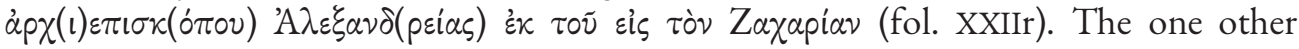
occasion on which Cyril is identified as Archbishop of Alexandria is in the heading of 1221. Cyril's Commentary on Luke in Greek, preached as a series of homilies, survives in fragments, most of which are in catenae: only the text of Homilies 3 and 4 is directly transmitted in a single Greek manuscript. ${ }^{46} \mathrm{~A}$ much fuller text of the Homilies is, as has been noted above, extant in Syriac, edited and translated by Payne Smith. ${ }^{47}$ However, Homily 1 in Syriac begins at Luke 2:1, suggesting that the commentary did not include the first chapter of the gospel. Cyril's exegetical fragments on Luke 1, and those elsewhere which do not match the Syriac tradition, must come from other writings which have not been preserved. The most extensive source for these is the collection by Reuss, superseding earlier publications by Mai and Sickenberger. ${ }^{48}$

The Syriac text-which appears to be a very literal translation of the Greek-shows that many of the scholia in Codex Zacynthius consist of abbreviated passages from Cyril's homilies, occasionally with minor editorial adjustments. The indication $\kappa \alpha \iota \mu \varepsilon \tau$ ' $\partial \lambda \iota \gamma \alpha$ is used on several occasions to indicate that a section has been omitted. There are a few instances where the catena contains material not present in the Syriac, either through omission in that tradition or because it may have been added by a compiler or commentator. One example of this is an extra line in scholium 294-3, commenting on the interpretation of Luke 10:22 ('No-one knows who the Son is except the Father ...', fol. LXXXr):

\footnotetext{
${ }^{45}$ See page 67 above.

${ }^{46}$ Paris, BnF, Coisl. gr. 274, fol. 180v-187r, printed in PG 77, 1040-9.

${ }^{47}$ The majority of the commentary is in two volumes from the eighth century, London, British Library, MS Add. 14551-2, which may be supplemented by other homiliaries also in the British Library. See Robert Payne Smith, The Gospel according to S. Luke by S. Cyril, Patriarch of Alexandria. Now first translated into English from an Ancient Syriac Version. 2 vols (Oxford: OUP, 1859).

${ }^{48}$ Reuss, Lukas-Kommentare; Joseph Sickenberger, Fragmente der Homilien des Cyrill von Alexandrien zum Lukasevangelium. TU 34 (Leipzig: Hinrichs, 1909); Angelo Mai, Bibliotheca nova Patrum. Tomus IV (Rome: Vatican, 1847).
} 


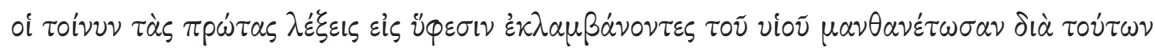

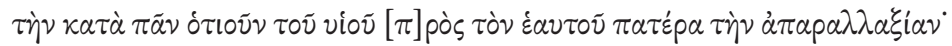

Accordingly, let those who take the first phrase as a subordination of the Son learn through these words the indistinguishability in every single thing of the Son with regard to his Father.

The entire scholium 279-2, with a reference to Elisha to illustrate Luke 10:4, cannot be found in Syriac but is relatively widespread in Greek catenae. In contrast, scholium 296-1 ends unexpectedly (there is no clause with a postpositive $\delta \dot{\varepsilon}$ following the initial clause with $\left.\mu \varepsilon^{\prime} \nu\right)$ and it is only in the Syriac version of Homily 67 that the logical conclusion of the comment may be seen. Comparison of Codex Zacynthius and the Syriac homilies has resulted in the new attribution of three fragments to specific homilies (171-2, 198-1 and 329-1), none of which appears in Reuss.

The complexity of the material and the significance of the Syriac may be seen in scholium 188-2 on Luke 7:6. Sickenberger edited this passage as a fragment from Titus' Commentary on Luke, but Reuss - who splits the extract into two-assigns it to Cyril. ${ }^{49}$ Not only is the first part preserved under Cyril's name in a manuscript of the catena C132, but the whole scholium in Codex Zacynthius is an abbreviated version of a passage in the Syriac text of Cyril's Homily 35 on Luke. ${ }^{50}$ In the catena by Nicetas of Heraclea (C135),

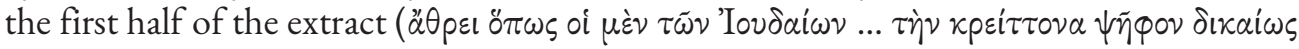
$\ddot{\eta} \rho \pi \alpha \sigma \varepsilon \nu)$ is embedded in a comment attributed to Titus of Bostra, while the latter part of

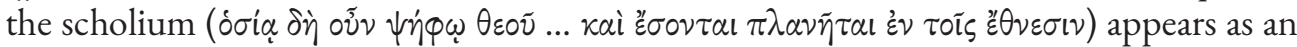
independent extract from Cyril (see Table 6.4). ${ }^{51}$ Between these two extracts, the catena in Codex Zacynthius (and in Paris, BnF, suppl. gr 612) has a quotation of Luke 7:9 and an additional comment, both of which are marked in bold in Table 6.4. The only parallel in

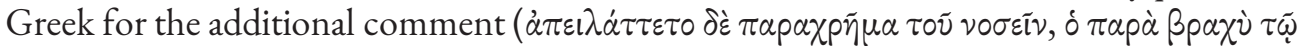

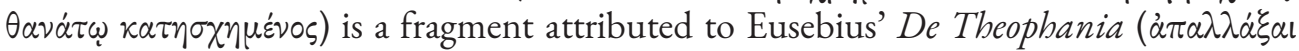

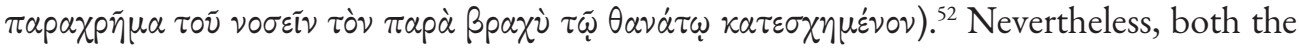
biblical quotation and this extra sentence appear between the two extracts in the Syriac version of Cyril's homily: the only difference between this and the scholium in Codex Zacynthius is the omission of two sentences (marked in italics in Table 6.4). At the same time, the fact that the scholia in both Codex Zacynthius and Nicetas' catena go on to omit the same lengthy portion present in the Syriac text of this sermon before resuming with

\footnotetext{
${ }^{49}$ Sickenberger, Titus von Bostra, 164-5; Reuss, Lukas-Kommentare, 72-3.

50 The manuscript is Vienna, ÖNB, theol. gr. 117 (fol. 142v). For the Syriac version, see Payne Smith, The Gospel according to S. Luke, 130.

${ }^{51}$ See Iviron 371, fol. 282v-283r. The latter part is also printed in PG 72, cols. 608-9, which relies

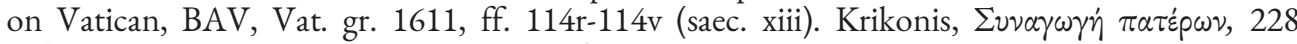
indicates erroneously that the passage is on $\mathrm{f} .114 \mathrm{v}$ in Vaticanus gr. 1611.

${ }^{52}$ Fragment 5 in H. Gressmann, Eusebius: Werke, Band 3.2: Die Theophanie. GCS 11.2 (Leipzig: Hinrichs, 1904), $3^{*}-35^{*}$.
} 


\begin{tabular}{|c|c|c|}
\hline $\begin{array}{l}\text { C137.3 } \\
\text { (Codex Zacynthius) }\end{array}$ & $\begin{array}{l}\text { C135 } \\
\text { (Iviron 371) }\end{array}$ & $\begin{array}{l}\text { yriac text of Cyril } \\
\text { trans. Payne-Smith) }\end{array}$ \\
\hline 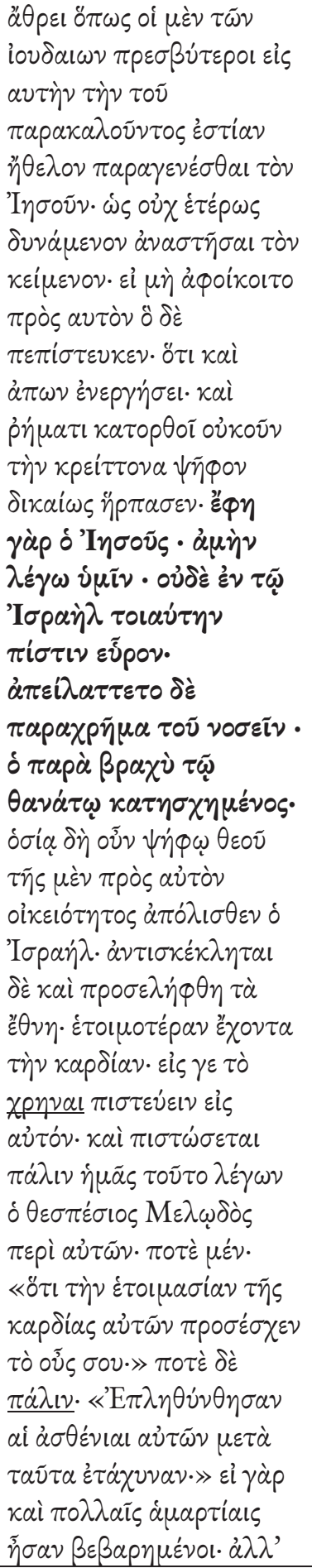 & 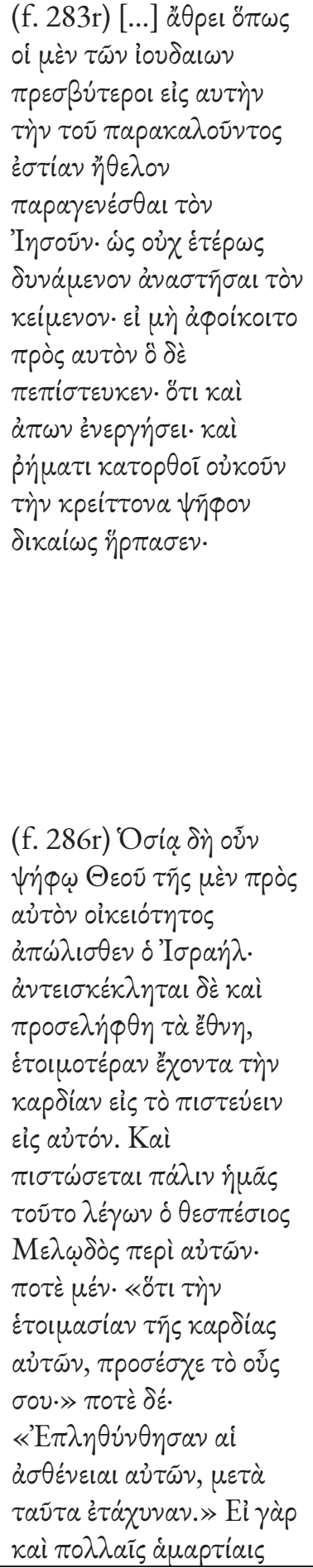 & $\begin{array}{l}\text { Consider then, that these elders of } \\
\text { the Jews begged Jesus to go to the } \\
\text { house of him who requested his } \\
\text { aid, as not being able in any other } \\
\text { way to raise him up who was lying } \\
\text { ill, except by going to his side:- } \\
\text { whereas the other believed that he } \\
\text { could do it even at a distance, and } \\
\text { effect it by the inclination of his } \\
\text { will. He asked for the saving word, } \\
\text { the loving assent, the all mighty } \\
\text { utterance; and justly therefore did } \\
\text { he win a sentence of surpassing } \\
\text { worth: for Jesus said, "Verily I } \\
\text { say unto you, that not even in } \\
\text { Israel have I found so great } \\
\text { faith." The proof then and } \\
\text { demonstration, follows closely and } \\
\text { immediately from what we have } \\
\text { now said. Finally, he delivered } \\
\text { that same hour from his } \\
\text { sickness him who a little before } \\
\text { had been the prey of death: for } \\
\text { he who willed the undoing of what } \\
\text { had happened was God. As I said } \\
\text { then at the beginning of this } \\
\text { discourse, by God's holy decree } \\
\text { Israel fell from his relationship } \\
\text { unto him, and in his stead the } \\
\text { heathen were called and admitted, } \\
\text { as having a heart better prepared } \\
\text { for that faith in him, which justly } \\
\text { is required. And of this the divine } \\
\text { Psalmist shall again be our proof, } \\
\text { where he says concerning them; at } \\
\text { one time, "Thou hast inclined } \\
\text { thine ear because of the } \\
\text { preparation of their heart;" and at } \\
\text { another, "Many were their } \\
\text { infirmities, and afterwards they } \\
\text { went quickly." For many indeed } \\
\text { were the offences laid to their }\end{array}$ \\
\hline
\end{tabular}




\begin{tabular}{|c|c|c|}
\hline 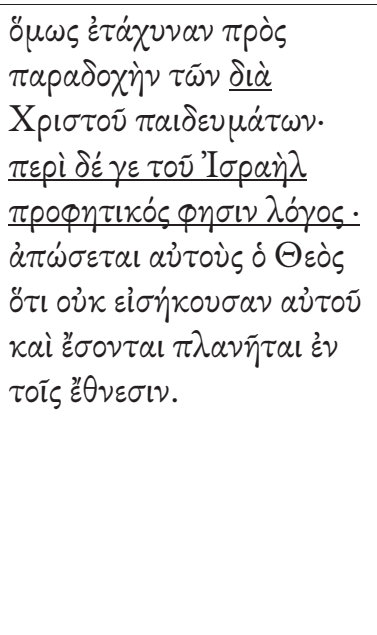 & 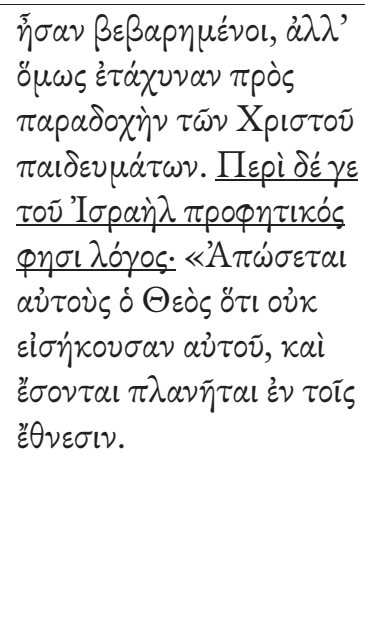 & $\begin{array}{l}\text { charge, to which be gently gives the } \\
\text { name of infirmities: for they were } \\
\text { wandering in error, and guilty of } \\
\text { abominable crimes, not merely in } \\
\text { one way, but in many: but they } \\
\text { went quickly to the faith, that is, } \\
\text { they were not slow in accepting the } \\
\text { commands of Christ, but very } \\
\text { readily embraced the faith. [Seven } \\
\text { sentences omitted by both catena } \\
\text { extracts.] And again; "God hath } \\
\text { rejected them, because they have } \\
\text { not heard him: and they shall be } \\
\text { wanderers among the heathen." }\end{array}$ \\
\hline
\end{tabular}

Table 6.4: Scholium 188-2 and parallels.

the same final quotation, introduced by the identical editorial comment which does not have a parallel in the Syriac, indicates that - for the latter part of the scholium at leastthe catena of Nicetas shares a source with Codex Zacynthius.

A similar situation in a passage attributed to Cyril but not extant in Syriac is seen in the comment on Luke 5:46 (scholium 158-1, fol. XXXIVv). Again, this scholium is found in a shorter form in the catena of Nicetas (C135), which is lacking a portion of text including two biblical quotations:

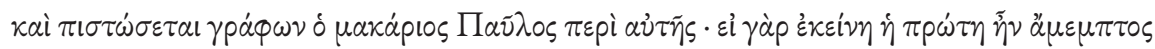

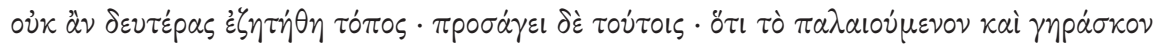

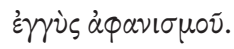

These citations of Hebrews 8:7 and 8:13 present the context for the previous reference in the scholium to the first covenant as growing old. The question is whether they might originally have been in Cyril's text and omitted by Nicetas, or whether they are an addition by the compiler of the Zacynthian catena (as they are also present in C137.7). Cyril quotes these verses elsewhere, such as in his Glaphyra in Pentateuchum. ${ }^{53}$ The introduction is a common phrase, variants of which are embedded in Cyril's commentaries such as kai

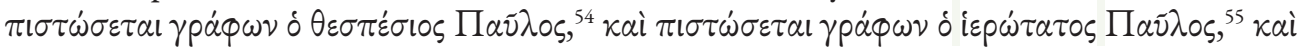

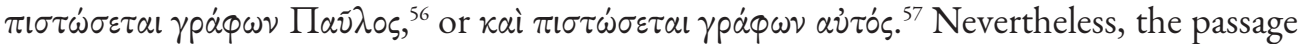
in the Zacynthian catena differs from all of these in using the adjective $\mu \alpha \alpha \dot{\alpha}$ pros of Paul,

\footnotetext{
${ }^{53}$ PG 69, 9-678.

${ }^{54}$ Commentarius in epistulam ad Hebraeos; J.A. Cramer, Catenae Graecorum Patrum in Novum Testamentum, VII (Oxford: OUP, 1843), 159.

${ }^{55}$ Commentarius in Isaiam prophetam; PG 70, 892.

${ }^{56}$ Commentarii in Lucam; PG 72, 837.

${ }^{57}$ Catena in epistulam I ad Corinthios; J.A. Cramer, Catenae Graecorum Patrum in Novum Testamentum V, (Oxford: OUP, 1841), 231.
} 
which casts doubt on this as being from the pen of Cyril. There are further differences between the witnesses to these catenae, as shown in Table 6.5:

\begin{tabular}{|c|c|c|c|c|c|c|c|}
\hline C135 & $\lambda \varepsilon^{\prime} \gamma \omega \nu$ & 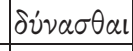 & 一 & 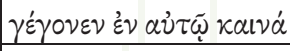 & - & - & $\varepsilon \dot{\theta} \theta \dot{v}$ \\
\hline C137.3 & - & 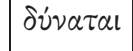 & $\pi \alpha \lambda \alpha 10 \tilde{v}$ & 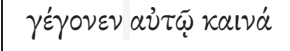 & raxáplos & ơ̈ $\tau \omega \lambda \varepsilon^{\prime} \gamma \omega \nu$ & $\varepsilon \dot{v} \theta \dot{\varepsilon} \varsigma$ \\
\hline C137.7 & & & & & & & \\
\hline
\end{tabular}

Table 6.5: Textual variants in scholium 158-1.

This table shows that the Zacynthian catena C137.3 and its descendant C137.7 also include the adjective $\mu \alpha x \alpha \dot{p}$ ios before the name David preceding the quotation from Psalm 51. This may tip the balance towards an insertion by the compiler, but it remains possible that this adjective was omitted by Nicetas.

In scholium 219-1, on Luke 8:13, there is some overlap between the different Synoptic accounts:

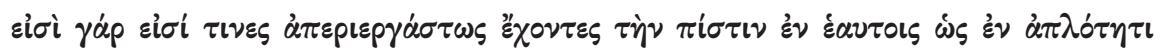

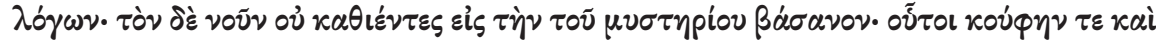

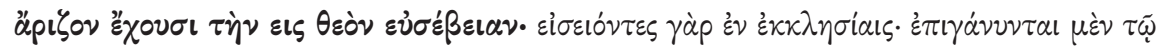

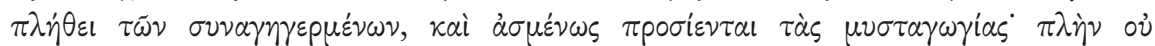

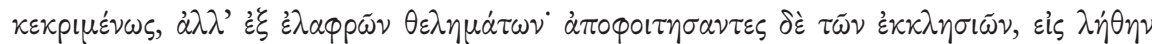

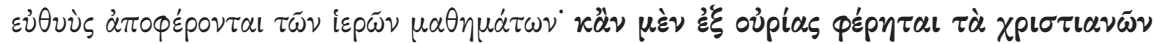

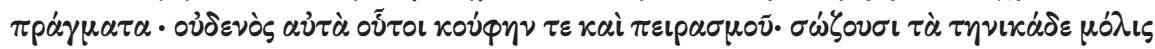

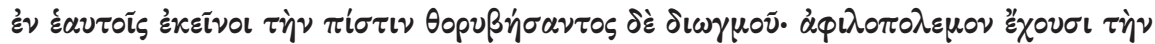

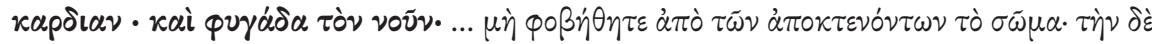

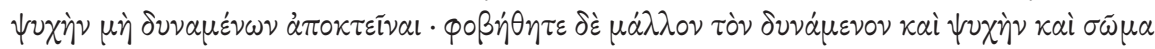
$\dot{\alpha} \pi 0 \lambda \dot{\varepsilon} \sigma \alpha l \dot{\varepsilon} \nu \gamma \varepsilon \dot{\varepsilon} \nu \nu \eta \cdot . .$.

The first section of this scholium corresponds verbatim to a continuous passage in the Syriac version of Cyril's Homily 41 on Luke. However, the two sections in bold type in the quotation above also appear within a scholium from Cyril on Matthew 13:19-22, which is actually a much longer excerpt from Homily $41 .^{58}$ In addition, the biblical verse at the end of the extract is not from Luke (despite its identification by Payne-Smith as Luke 12:4), but is rather Matthew 10:28. This shift is not surprising given that Cyril appears to have delivered these homilies verbally, and there are frequent discrepancies in the biblical quotations. ${ }^{59}$ Nevertheless, the use of text from a Lukan homily in a catena on Matthew is striking. The extra material in the Zacynthian catena, plus several minor textual differences, suggests that the two scholia were drawn from the Homilies on Luke independently. ${ }^{60}$ This passage is not found in manuscripts of the catena $\mathrm{C} 131$; an abridged form is present in C132, C133 and C134, and a slightly different abbreviation of it is

\footnotetext{
${ }^{58}$ Reuss, Matthäus-Kommentare, 207-8 (frag. 168), where it is correctly identified as coming from the Homilies on Luke.

${ }^{59}$ See further Payne-Smith's observations quoted on page 53 above.

${ }^{60}$ The text in Codex Zacynthius is also present in C137.7 (Paris, BnF suppl. gr. 612, fol. 225v).
} 
found in C135, in which the latter part of the quotation from Matthew is replaced by the phrase kai $\tau \dot{\alpha} \dot{\xi} \xi \tilde{\eta} \xi$ ('and what follows'). ${ }^{61}$

In addition to the examples of textual differences already given, we may note several instances where the catena in Codex Zacynthius transmits a different reading to that of the other witnesses to the text of Cyril's commentary, which is a synonym. These are presented in Table 6.6:

\begin{tabular}{|c|c|c|}
\hline Scholium & Other witnesses & Codex Zacynthius \\
\hline $128-2$ & $\lambda \alpha \beta \omega^{\prime} \nu$ & $\lambda \alpha \chi \omega^{\prime} \nu$ \\
\hline $152-1$ & $\pi 0 \lambda \lambda \alpha_{\alpha} k \iota \varsigma$ & ยั $\sigma \theta$ ' ö $\tau \varepsilon$ \\
\hline $182-1$ & 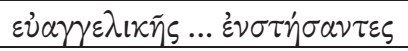 & $\varepsilon \dot{v} \alpha \gamma \circ \tilde{v} \varsigma \ldots \alpha \dot{\alpha} \nu \alpha \sigma \tau \dot{\eta} \sigma o \nu \tau \varepsilon \varsigma$ \\
\hline $219-1$ & kapdíav & $\psi v x \eta \dot{\eta}$ \\
\hline $249-2$ & $\dot{\varepsilon} \kappa \tau \varepsilon \lambda \varepsilon \sigma \mu \alpha \dot{\alpha} \tau \omega \nu$ & $\dot{\alpha} \pi \circ \tau \varepsilon \lambda \varepsilon \sigma \mu \dot{\alpha} \tau \omega \nu$ \\
\hline $271-3$ & $\varepsilon \delta \delta \delta \dot{\alpha} \sigma \kappa O \nu \tau O$ & 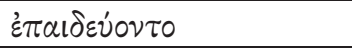 \\
\hline $278-1$ & $\theta \varepsilon \tilde{I} о \mathrm{~S}$ & $\theta \varepsilon \sigma \pi \varepsilon^{\prime} \sigma l \circ \zeta$ \\
\hline $296-1$ & 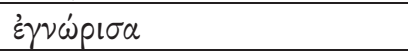 & $\dot{\alpha} \nu \eta^{\prime} \gamma \gamma \varepsilon i \lambda \alpha$ \\
\hline
\end{tabular}

Table 6.6: Synonymous readings in Cyril scholia.

The Syriac homilies cannot be used in order to judge between these variants. Other types of catena vary: for example, $\mathrm{C} 131$ has $\lambda \alpha \beta \omega \dot{\nu}$ in the passage equivalent to $128-2$, but sides

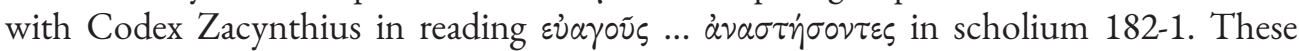
different readings need to be considered in the light of Cyril's usage to determine whether Codex Zacynthius preserves a more ancient text of Cyril which was adjusted by other compilers in different catena traditions, or whether the re-writing is a characteristic of this catena. For example, the use of $\theta \varepsilon \sigma \tau \varepsilon \dot{\varepsilon} \sigma$ เos only in four other extracts from Cyril (188-2, 219-1, 258-1, 262-2) and nowhere else in this catena, along with no examples of $\theta$ rios as an epithet for Paul, suggests that Codex Zacynthius may be closer to the original. One stylistic trait of Cyril evident in these scholia is a repeated verb separated by $\gamma \dot{\alpha} \rho$ : in addition to the

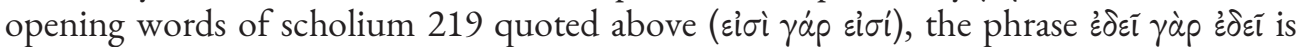
found in scholia 142-1, 249-2 and 255-2.

\section{Victor the Presbyter}

Seven short scholia in Codex Zacynthius are attributed to the fifth-century Victor the Presbyter. ${ }^{62}$ Although scholium 037-1 is transmitted under the name of Victor of Antioch in the catena by Nicetas of Heraclea (C135), it actually appears to be from Severus (see

${ }^{61}$ On these different catena types, see Chapter 8 below. It may be observed that Reuss, LukasKommentare, 81 does not present all of the variant readings in the manuscripts of this scholium.

${ }^{62}$ 010-1 on Luke 1:5; 052-1 on Luke 1:50; 070-1 and 071-1 on Luke 1:77; 222-1 on Luke 8:17; 223 1 and $224-1$ on Luke 8:18. 
below). ${ }^{63}$ Victor is better known for his commentary on Matthew, and it is not clear from which of his works these passages have been taken. The majority are encountered in the catena on Luke by Nicetas of Heraclea (C135), in which Sickenberger identified twentyfour passages from Victor; four are also present in Cramer's edition of the catena on Luke (C131). ${ }^{64}$ Nevertheless, three of the scholia appear not to be present in other published catenae, namely $010-1,070-1$ and $071-1$ : in the case of the last two, folio XVr is too poorly preserved to permit reading them in their entirety.

\section{Severus of Antioch}

Thirty-one extracts in Codex Zacynthius are nominally assigned to Severus of Antioch (c.465-538). As noted in Chapter Five, there is some inconsistency in whether or not Severus is given the title $\ddot{\alpha} \gamma$ los ('saint'), but there is no evidence of any attempt to erase Severus' name. ${ }^{65}$ Although Severus never wrote a commentary on any book of the Bible, his homilies and letters were popular with the compilers of catenae. In common with other catena collections, many of the extracts from Severus in Codex Zacynthius include details of the work from which they are taken. ${ }^{66}$ It has been possible to identify six other passages from Severus based on Mai's collection: despite the age of this collection and its reliance on just two Vatican manuscripts, the fact that it coincides with most of the scholia identified as Severus in Codex Zacynthius lends credence to its other attributions. ${ }^{67}$ Given the rarity of Severus' writings, the attributions of the scholia are given in Table 6.7.

\begin{tabular}{|l|l|}
\hline Work & Scholia \\
\hline Sermon 2 & $030-2,031-1,032-2,033-1$ \\
\hline Sermon 32 & $024-2,064-2$ \\
\hline Sermon 33 & $005-3$ \\
\hline Sermon 36 & $077-2,080-2,081-1$ \\
\hline Sermon 51 & $241-3$ \\
\hline Sermon 63 & $038-2,038-3$ \\
\hline Sermon 82 & $268-3$ \\
\hline Sermon 89 & $300-1,300-2,301-1$ \\
\hline
\end{tabular}

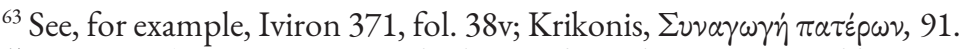

${ }^{64}$ Joseph Sickenberger, Die Lukaskatene des Niketas von Herakleia. TU 22.4 (Leipzig: Hinrichs, 1902), 97. The passages are published in Angelo Mai, Scriptorum veterum nova collectio, Tomus IX (Rome: Vatican, 1837), 626-720. Lamb has convincingly argued against Smith's proposition that Victor of Antioch was a compiler of a catena on Luke (W.R.S. Lamb, The Catena in Marcum: A Byzantine Anthology of Early Commentary on Mark. TENT 6(Leiden: Brill, 2012), esp. 40-47). ${ }^{65}$ See pages 21 and 65; on the erasure claimed by Tregelles, see J.H. Greenlee, 'The Catena of Codex Zacynthius,' Biblica 40 (1959): 992-1001, esp. 998-9.

${ }^{66}$ On the use of Severus' writings, in particular in exegetical collections on the Catholic Epistles, see Karl Staab, 'Die griechischen Katenenkommentare zu den katholischen Briefen,' Biblica 5 (1924): 269-353; J.H. Ropes, 'The Greek Catena to the Catholic Epistles,' Harvard Theological Review 19 (1926): 383-8; Yonatan Moss, 'Saving Severus: How Severus of Antioch's Writings Survived in Greek,' GRBS 56 (2016): 785-808, and the discussion in Chapter 7 below.

${ }^{67}$ Angelo Mai, Classicorum auctorum e Vaticanis codicibus editorum. Tomus X (Rome: Collegium Urbanum, 1838) 408-457, 470-3.
} 


\begin{tabular}{|l|l|}
\hline Sermon 113 & $174-2$ \\
\hline Sermon 115 & $037-1$ \\
\hline Sermon 118 & $203-2,203-3$ \\
\hline Against the Apology of Julian & $252-2$ \\
\hline Against the Testament of Lampetius & $123-2$ \\
\hline Apology of Philalethes & $260-3$ \\
\hline Letter to Anastasia the Deacon & $204-1,204-2$ \\
\hline Letter to Caesaria the Noblewoman & $082-1$ \\
\hline $\begin{array}{l}\text { Letter to Kyriakos and the other } \\
\text { Orthodox Bishops in Constantinople }\end{array}$ & $252-3$ \\
\hline $\begin{array}{l}\text { Letter to Sergius the Chief Physician, } \\
\text { who asked why the Lord only took Peter } \\
\text { and James and John }\end{array}$ & $259-3$ \\
\hline On Numbers & $072-2$ \\
\hline No work title & $029-1,044-3,044-4,076-2,171-1,299-1$ \\
\hline$\dot{\xi} \xi \dot{\alpha} v \pi$ r $\gamma$ á $\varphi$ ov & $043-1,072-1$ \\
\hline
\end{tabular}

Table 6.7: Attribution of scholia from Severus of Antioch.

Only two of these attributions can be verified from outside the catena tradition: the letters to Caesaria and Sergius are preserved in Syriac, which also includes four letters to Anastasia the Deacon but not the one cited in Codex Zacynthius. ${ }^{68}$ The identification of others is plausible from characteristic vocabulary in Mai's collection: for example, Severus is responsible for four of the five occurrences of the word $\varphi \alpha v \tau \alpha \sigma i \alpha$ in Codex Zacynthius (folios XIr, XVr, XIXv and LXXXIIIv; the exception is Basil on fol. XXIr) and the only instance of $\varphi^{\prime} \alpha \nu \tau \alpha \sigma \mu \alpha$ (fol. XIv). Similarly colourful terms include $\chi \alpha \mu \alpha i \zeta \eta \lambda o s$ (fol. LXVIIr) and $\beta \delta \varepsilon \lambda$ upós (fol. XIr).

Other attributions are problematic. It is surprising to find two extracts from Severus with the title $\dot{\xi} \xi \dot{\alpha} v \varepsilon \pi \gamma \rho \dot{\alpha} \varphi \circ v$, as he is considerably later than the other scholia identified by this heading. ${ }^{69}$ While some scholia correspond almost verbatim to the texts printed by Mai, others are much looser. Despite the clear indication of scholium 260-3 as from Severus in Codex Zacynthius, it appears among the extracts from Cyril in Mai's collection. ${ }^{70}$ Although scholium 032-2 on fol. VIIIv is identified as Severus, Sermon 2, it has clear verbal overlap with fragments 24 and 25 of Origen in Rauer and a scholium attributed elsewhere

\footnotetext{
${ }^{68}$ See E.W. Brooks, ed. and trans. The Sixth Book of Select Letters of Severus, Patriarch of Antioch, in the Syriac Version of Athanasius of Nisibis (London: Williams and Norgate, 1902-4) and A Collection of Letters of Severus of Antioch from Numerous Syriac Manuscripts (Patrologia Orientalis 12 and 14. Paris: Firmin-Didot, 1919-20).

${ }^{69}$ As noted in the earlier section on this collection, scholium 072-1 (which occurs in the Severan section in Mai) is attributed by Heinrici to the even later Peter of Laodicea.

${ }^{70}$ Mai, Classicorum auctorum; Tomus X, 522.
} 


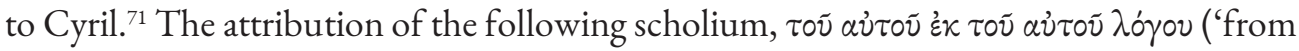
the same author from the same sermon'), implies that it is also from Severus, but it does not appear in Mai's collection, only in Cramer. Again, scholia 080-2 and 081-1, although attributed to Severus by Codex Zacynthius, are absent from Mai but match Rauer's

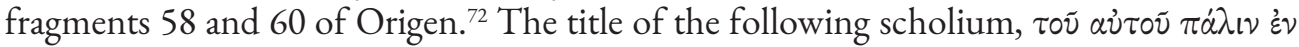
$i \pi \alpha \kappa \circ \tilde{n}$ ('from the same, again, in response'), appears to identify 081-2 (which also appears in Mai's collection) as Severan but it is attributed to Origen in the catena C131. ${ }^{73}$ Scholia 300-2 and 301-1, both indicated in Codex Zacynthius as Severus, also appear in the catena C131, where the latter is ascribed to Cyril. ${ }^{74}$ The identification of 037-1 is based on Codex Palatinus and the information given there about the sermon number.

Codex Zacynthius is clearly an important source for the Greek text of these extracts from Severus, some of which are lengthy: scholium 082-1 covers almost three pages of the manuscript, while 259-3 and 301-1 occupy two pages. Further comparison of these with the Severan scholia in Mai and other sources, including a more detailed examination of his characteristic vocabulary is required to resolve questions of authorship.

\section{Observations on Copying Practice in the Catena}

The examination of the texts of the scholia has also provided the occasion to make some observations regarding the copying of the catena. First, it may be noted that the use of accents and breathings is not consistent throughout the catena text. ${ }^{75} \mathrm{~A}$ large part of the preface to the catena (f. Ir) as well as long passages on $\mathrm{f}$. XVIIIv and f. LXXr are accented. In the rest of the manuscript the catena text is only occasionally accented: an angular-shaped daseia (') is often placed over initial upsilon and a varia (') is placed above the word $k \alpha$. Greek dialytika (") are often placed over initial iota. This provides yet another instance of the discontinuities in presentation observed in Chapter 3.

Images of the abbreviations used in the catena text have already been presented in Table 3.1. These include the replacement of the final $n u$ at the end of a line by a supralinear stroke and the occasional use of a line for $\alpha \iota$ and $\alpha$. Commas occur infrequently: the majority of these follow one of two words: $\gamma$ áp (folios Ir, XIIv, XVIv, XVIIIr, XVIIIv, XXIIr, XXIXr [thrice], XXXIv, XXXIVv, XXXVr, LXIVr and LXXv) and 'E $\lambda ı \sigma \alpha ́ \beta \varepsilon \tau$ (folios IXr [twice], $\mathrm{IXv}$ [four times], Xv [twice], XIv [twice], XIIr, XIIIv [thrice], XIVr).${ }^{76}$ The nomina sacra

\footnotetext{
${ }^{71}$ Cf. PG 72, 549, 21-2.

${ }^{72}$ These excerpts are copied under the name of John Chrysostom in Paris, BnF, suppl. gr. 612, fol. $191 \mathrm{v}$.

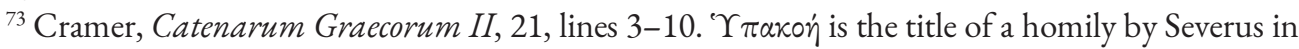
a papyrus fragment (CPG 7039).

${ }^{74}$ Cramer, Catenarum Graecorum II, 88, lines 15-25 and 88, line 29-89, line 19. The passage which is scholium 301-1 also appears in Theophylact's catena.

${ }^{75} \mathrm{On}$ accents and breathings in the gospel text, see page 22 above.

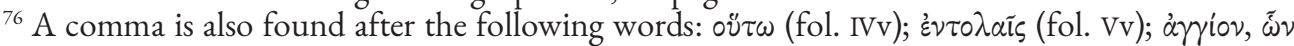

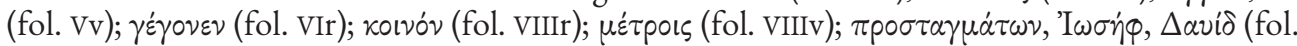

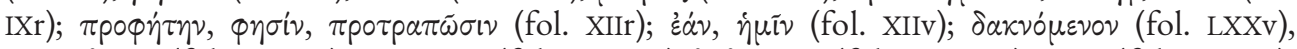
$\varepsilon \dot{\nu} \alpha \gamma \gamma \varepsilon \lambda \iota \kappa \eta^{\prime} \nu$ (fol. LXXIVr); $\alpha i \tau o \dot{\nu} \nu \tau \omega \nu$ (fol. LXXVIIr), $\lambda \alpha \lambda \circ \tilde{\nu} \nu \tau \varepsilon \varsigma$ (fol. LXXVIIIr); $\dot{\varepsilon} \sigma \tau i \nu$ (fol. LXXIXr),
} 
abbreviations are in frequent use, but there are occasions on which these words are written

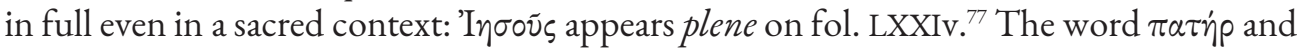
its derivatives occur in full when they do not refer to God: the words $\pi \alpha \tau \varepsilon$ ' $\alpha$ on fol. Vr, $\pi \alpha \tau$ pós on XIVr and $\pi \alpha \tau \dot{p} \rho$ on XIVv refer to Zechariah, the father of John; the $\pi \alpha \tau \varepsilon$ ' $\alpha$ on fol. XXIIIv identifies Abraham; the $\pi \alpha \tau \varepsilon \rho \alpha$ and $\pi \alpha \tau$ pós on fol. LXIXr refer to the father of a boy with a demon (Luke 9:37); the $\pi \alpha \tau \dot{\eta} \rho$ and $\pi \alpha \tau \varepsilon$ ' $\alpha$ on fol. LXXIVr refer to the father of one of Jesus' disciples (Luke 9:59); the $\pi \alpha \tau \eta^{\prime} \rho$ on fol. LXXXIXv identifies Satan; the $\pi \alpha \tau \dot{\varepsilon} \rho \omega \nu$ on folios Ir and LXXIIv refer to the Holy Fathers; the $\pi \alpha \tau$ i i on fol. Ir refers to Cyril of Alexandria. $\Pi \nu \varepsilon \tilde{\nu} \mu \alpha$ is always abbreviated. ${ }^{78}$ The words $\pi \nu \varepsilon \nu \mu \alpha \dot{\tau} \tau \omega \nu$ on folios XVIIIv and XXIXr, and $\pi \nu \varepsilon v \mu \alpha \sigma \nu$ on $\mathrm{f}$. XXIXr are written in full and refer to evil spirits. ${ }^{79}$ The words

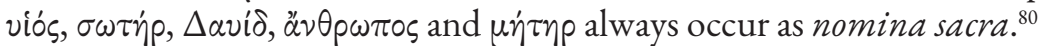

As to the orthography, there are a variety of simple copying errors which may be divided in to several categories. The first comprises the omission or repetition of a letter,

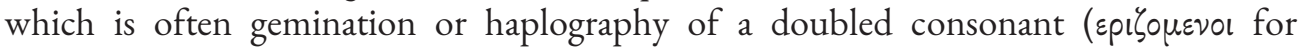

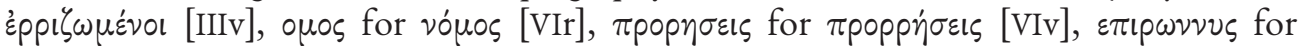

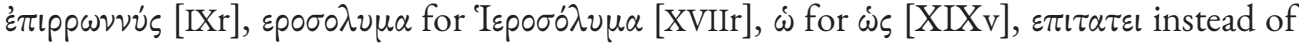

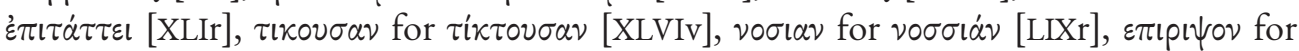

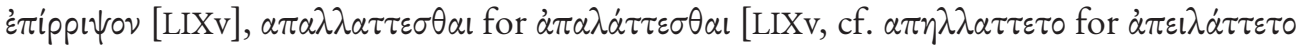

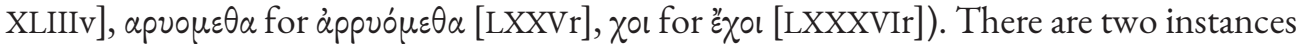

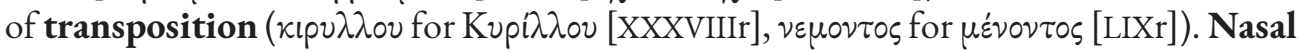
consonants are sometimes switched or otherwise unstable ( $\sigma \varepsilon \rho \alpha \varphi \nu$ for $\sum \varepsilon p a \varphi i \mu$ [XVIIv], $\varepsilon \nu \chi \omega \nu \nu \nu \tau \alpha l$ for $\dot{\gamma} \gamma \chi \omega \nu \nu \tau^{\tau} \alpha l$ [LIIr], $\varepsilon \mu \mu \varepsilon \sigma \omega$ for $\dot{\varepsilon} \nu \mu \dot{\varepsilon} \sigma \omega$ [LIVv]).

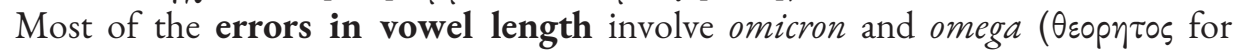

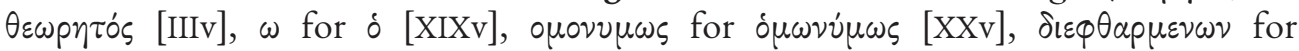

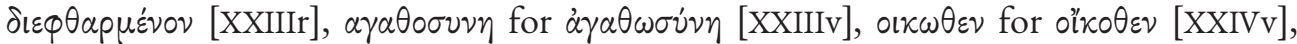
$\alpha \lambda \circ \nu \alpha$ for $\ddot{\alpha} \lambda \omega \nu \alpha$ [XXVr], $\alpha \pi \circ \lambda \iota \sigma \theta \varepsilon$ for $\alpha \pi \dot{\omega} \lambda \iota \sigma \theta \varepsilon$ [XXXVIr; also XLIIIv], $\alpha p \chi \omega \nu \tau \iota$ for $\ddot{\alpha} p \chi o \nu \tau \iota$

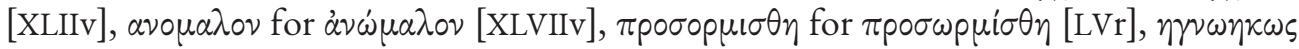

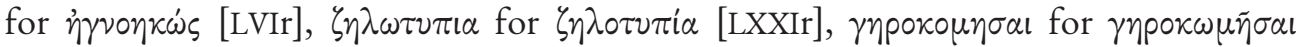

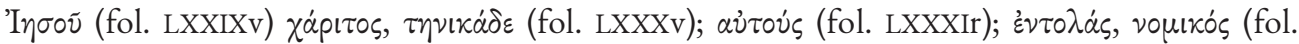

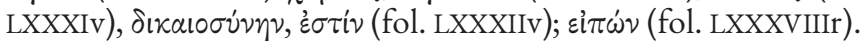

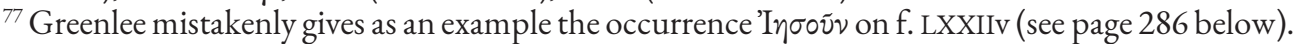

${ }^{78}$ Folios XIIv, XIIIr, XVv, XXIVv, XXVr, XXVIr, XXVIIr, XXXIVv, XLv, XLVv, XLVIv, XLVIIr, LXIIv, LXXIIr, LXXVr, LXXVIIIr, LXXXIVv.

${ }^{79}$ It is worth noting that $\pi \nu \varepsilon \tilde{\nu} \mu \alpha$ normally occurs in full for evil spirits in the Gospel text: see page 47 above.

${ }^{80} \sum \omega \tau \ln ^{\circ}$ : folios IVr, Xr, XIIIr, XXIIIr, XXXIr, XXXIIIr, XXXVr, XXXVv, XXXVIr, XLv, LIr, LIIv, LIIIr, LIVr, LVr, LVIIIv, LXVIv, LXXv, LXXIv, LXXIIv, LXXVIv, LXXIXv, LXXXv, LXXXIV, LXXXIIv, LXXXVIIr,

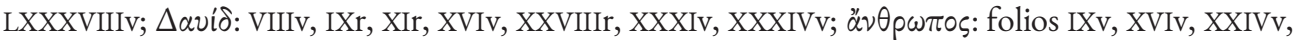
XXVr, XXVIr, XXVIv, XXXIIr, XLVIr, XLVIIIr, LIXr, LXIIr, LXVIIV, LXXIXv, LXXXr, LXXXIIIv, LXXXIVr,

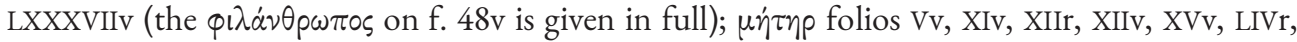
LIVv. On the nomina sacra in the Gospel text, see page 47 above. 


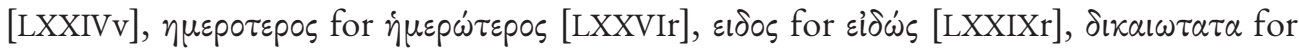
$\delta ı \kappa \alpha เ o ́ \tau \alpha \tau \alpha$ [LXXIXv], $\pi \nu \varepsilon \nu \mu \alpha \tau \iota \kappa o s$ for $\pi \nu \varepsilon \nu \mu \alpha \tau i \kappa \tilde{\omega} \varsigma$ [LXXXVIIv]). ${ }^{81}$ This also occurs twice

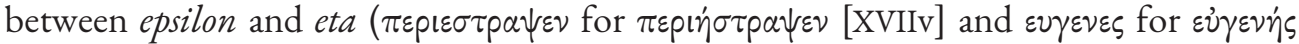
[XLVIv]).

The interchange between $\alpha \mathrm{l}$ and $\varepsilon$ reflects a common sound change ( $\gamma \nu \nu \varepsilon \kappa o s$ for

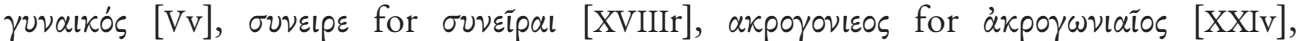

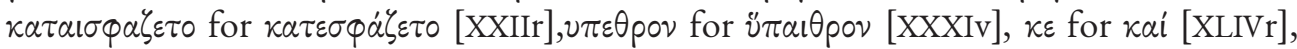

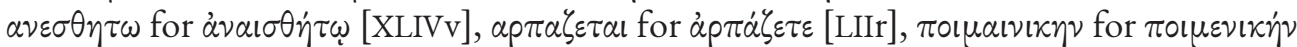
[LXIv], $\alpha \iota \lambda \varepsilon \iota \mu$ for 'E $\lambda \varepsilon i \mu$ [LXXVr], $\tau \imath \theta \varepsilon \sigma \theta \alpha \iota$ for $\tau i \theta \varepsilon \sigma \theta \varepsilon$ [LXXVIr]). Less expected

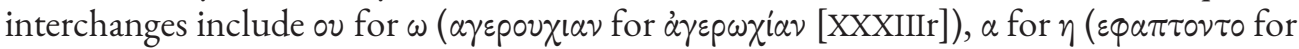

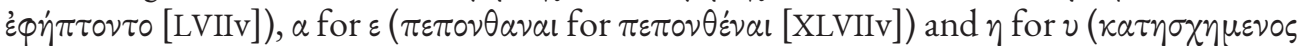
for $\kappa \alpha \tau \eta \propto \chi \nu \mu \varepsilon ่ \sigma s$ [XLIIIV]

The most common errors by far are of itacism involving $\varepsilon \iota, \eta, \iota$ and $o$ in the following

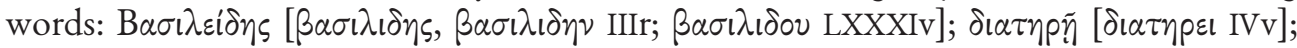

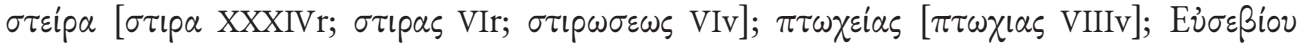

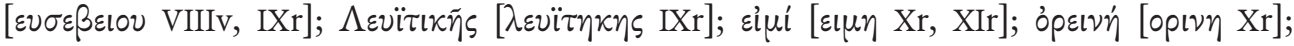

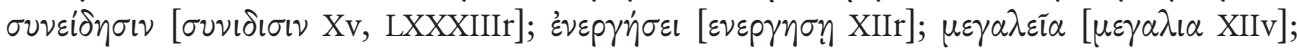

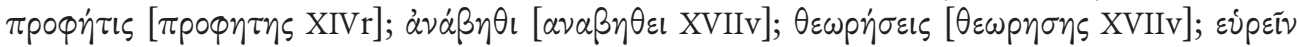

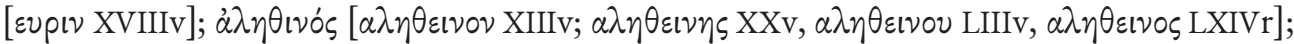

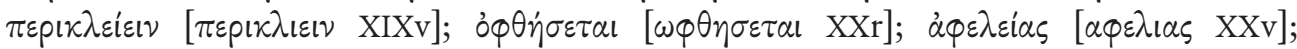

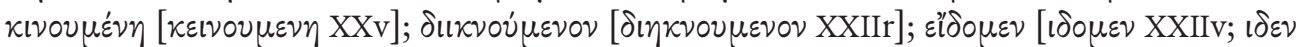

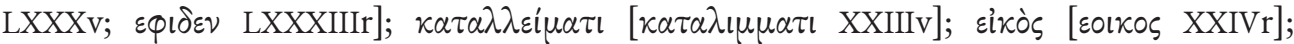

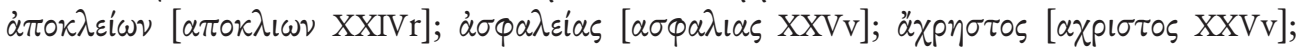

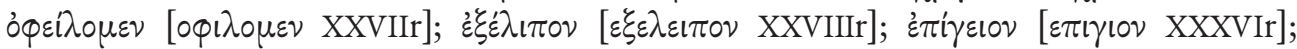

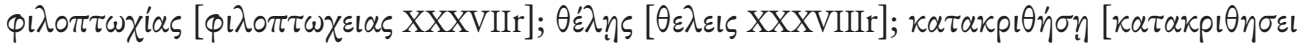

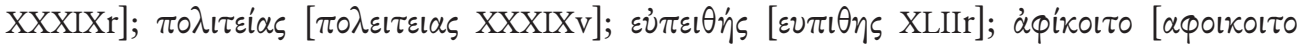

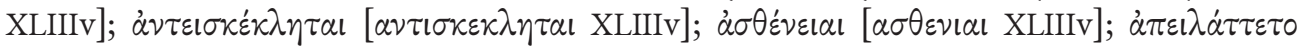

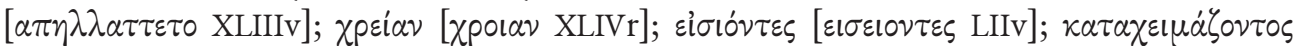

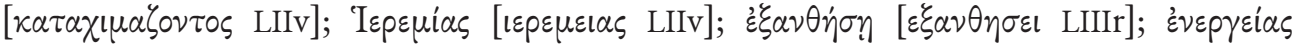

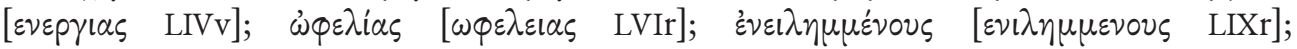

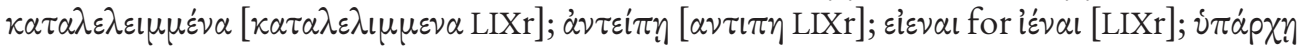

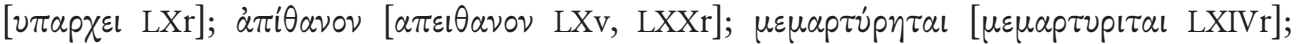
фı

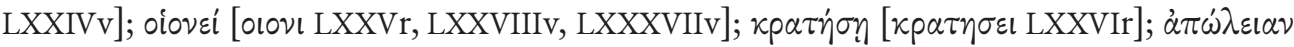

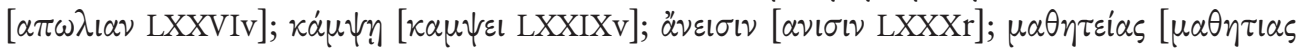

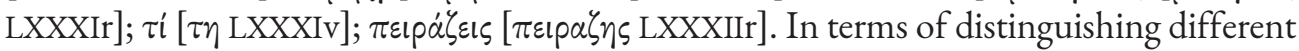
copyists, it may be significant that the spelling rovovov $\iota$ is found on XXVIv, XXXVv, XLIIV

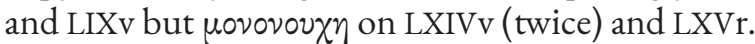

The following errors do not fit into any of the categories above: $\beta \varepsilon \beta \nu \omega \mu \varepsilon \nu \alpha$ for

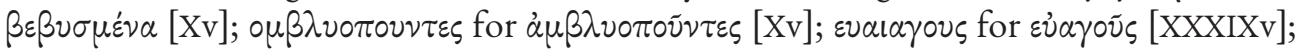

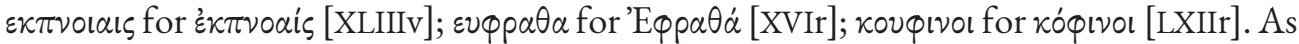
in the biblical text, the catena uses $\pi \alpha \nu \delta$ oxı

${ }^{81}$ Greenlee, 'The Catena of Codex Zacynthius,' 996 erroneously records that the catena at Luke

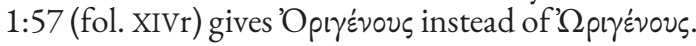




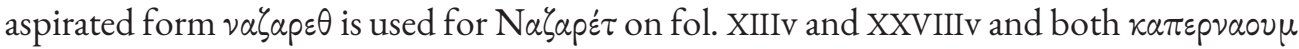

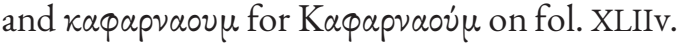

Several readings in which Codex Zacynthius differs from other catenae or the direct tradition of the patristic sources have already been noted in the first part of this chapter, especially in the section on Cyril of Alexandria. Most of these should probably be attributed to the compiler rather the copyist. Nevertheless, we may note that at the end of

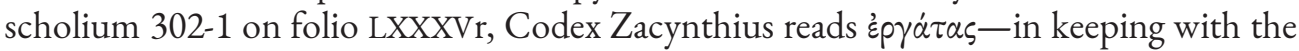

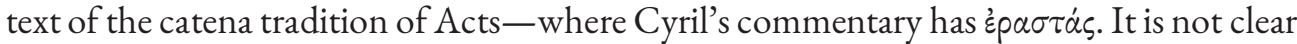
whether this closer correspondence with Acts material is due to the compiler or the copyist.

There is one instance on which it appears that the copyist of Codex Zacynthius has omitted a phrase due to homoeoteleuton. Folio LXr line 7 offers a nonsense reading without a main verb. Comparison with Reuss's extract 68 from Cyril of Alexandria reveals

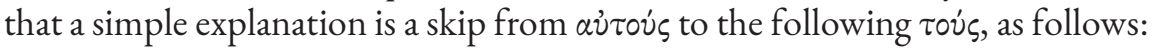

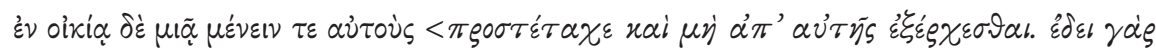

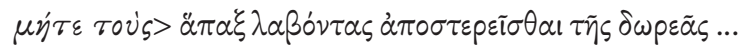

Although such a common form of omission cannot be used to determine the length of a line in the exemplar, it provides further evidence confirming the observations in earlier chapters that Codex Zacynthius is copied from another catena manuscript. ${ }^{82}$

\section{CONCLUSIONS}

The catena in Codex Zacynthius comprises exegetical passages on verses of the Gospel of Luke taken from ten named authors as well as what seems to be an early collection in which the passages were not identified by author (to which the heading $\dot{\varepsilon} \xi \dot{\alpha} \nu \varepsilon \pi \imath \gamma \rho \dot{\alpha} \varphi \circ$ is given). The majority of the scholia are from Cyril of Alexandria's commentary on Luke, originally preached as homilies, followed by the commentaries of Titus of Bostra and Origen. Severus of Antioch is quoted relatively frequently, sometimes at length, with detailed information about the works from which his extracts are taken. Basil of Caesarea, Eusebius of Caesarea, Isidore of Pelusium and Victor the Presbyter are quoted less frequently: the sources for their exegetical comments are shorter works, such as letters. A single extract is identified as from Apollinarius of Laodicea, which originally comes from his exegesis of a passage in Matthew. Similarly, the extracts from Chrysostom also originate in his exposition of Matthew while three of the scholia from Origen are from his Commentary on John. A scholium derived from Cyril's Homily 41 on Luke was also used independently in catenae on Matthew. This variety in the material deployed between gospels is noteworthy. At the same time, the selection of sources for Codex Zacynthius is remarkably narrow in comparison with some of the later catena traditions, such as that of Nicetas of Heraclea, with several well-known authors not represented at all.

\footnotetext{
${ }^{82}$ See pages 53 and 65 above.
} 
The majority of the scholia appear to be correctly identified, suggesting that Codex Zacynthius is a reliable witness to its compilation. Nevertheless, the high proportion of material which is only known through catena tradition means that it is not always possible to confirm the source, even though stylistic analysis may be of assistance. There are some errors in Codex Zacynthius, with attributions to Titus of Bostra of passages which derive from Cyril of Alexandria and overlaps between Origen and scholia assigned to Severus. Parallels elsewhere have enabled the project to identify the source of extracts whose title is missing or obscured, but there remain twenty-one passages which cannot be identified.

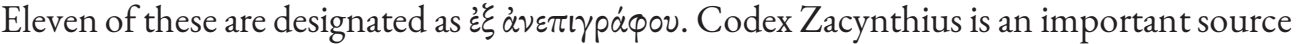
for the Greek text of Severus of Antioch, but there is also material from Titus of Bostra and Victor the Presbyter which has not yet been identified elsewhere. Most of the titles of the scholia are similar in form, which means that inconsistencies such as the first attribution to Titus of Bostra may be significant for the manner in which the catena was compiled.

More detailed analysis of the text of the scholia of Codex Zacynthius and comparison with other sources for the same passages has shown how these have often been reworked by the compilers. There are several occasions where Codex Zacynthius features additional biblical quotations not present in other catena types. More common, however, is the omission of material and the abbreviation of the original source. It frequently seems to be the case that catenae drew independently on the same sources: there are no indications that the catena of Codex Zacynthius derives from any of the other major types. Textual variations suggest that, particularly in the case of Cyril of Alexandria, Codex Zacynthius may preserve a text closer to the original source than other catenae, but fuller investigation of this is needed. Support for the reading in Codex Zacynthius is usually provided by the catena in Paris, BnF, suppl. gr. 612, a descendant of the same catena on Luke. This manuscript is considered in further detail in Chapter 8 , along with the relationship of Codex Zacynthius to the principal types of catena on Luke. The copying of the catena text has many similarities with that of the Gospel according to Luke, as might be expected: there are some discontinuities in practice which may be related to the activity of different copyists, as suggested in Chapter 3. 